\title{
The Sources behind "The Gifts and the Calling of God Are Irrevocable" (Rom 11:29): A Reflection on Theological Questions Pertaining to Catholic-Jewish Relations on the Occasion of the 50th Anniversary of Nostra Aetate (No. 4) \\ Commission of the Holy See for Religious Relations with the Jews December 10, 2015
}

\section{PHILIP A. CUNNINGHAM} pcunning@sju.edu Saint Joseph's University, Philadelphia, PA 19131

Note: This version of "Gifts and Calling" has been supplemented with footnotes to provide quotations or close quotations of often uncited allusions to earlier texts. The footnotes also provide selected references to topically relevant recent Catholic texts from the Vatican and the United States. ${ }^{1}$ The annotations are not exhaustive but do illustrate key points. A list of abbreviations used in the notes appears at the end.

This article was generated from the February 2016 Saint Joseph's University "Consultation on the Newest Statements about the Christian-Jewish Relationship."

\footnotetext{
${ }^{1}$ [Some texts from the United States Conference of Catholic Bishops are cited herein because this journal is published in the United States, but also because the world's largest Jewish diaspora population lives in close contact with large Catholic communities there. This has allowed the CatholicJewish dialogue in the United States occasionally to attain significant depth and duration. N.B.: "The vast majority of the (roughly) 14 million Jews in the world live in the United States and in Israel (approximately 11 million). In both countries, numerous dialogue initiatives are underway, even if the contexts are notably different: whereas in the United States, the Jewish community represents a small minority of the population, living alongside a great variety of Christian denominations, in Israel the situation is reversed: the Christian communities are a minority alongside the Jewish majority. In that country [Israel], however, the Jewish-Christian dialogue experiences the consequences of the political conflict, while in the United States - because of the religious freedom which has been asserted there since the beginning — this dialogue has become a real and true model” (Hoffman, 2013).]
} 


\section{PREFACE}

Fifty years ago, the declaration "Nostra aetate" of the Second Vatican Council was promulgated. Its fourth article presents the relationship between the Catholic Church and the Jewish people in a new theological framework. The following reflections aim at looking back with gratitude on all that has been achieved over the last decades in the Jewish-Catholic relationship, providing at the same time a new stimulus for the future. Stressing once again the unique status of this relationship within the wider ambit of interreligious dialogue, theological questions are further discussed, such as the relevance of revelation, the relationship between the Old and the New Covenant, the relationship between the universality of salvation in Jesus Christ and the affirmation that the covenant of God with Israel has never been revoked, and the Church's mandate to evangelize in relation to Judaism. This document presents Catholic reflections on these questions, placing them in a theological context, in order that their significance may be deepened for members of both faith traditions. The text is not a magisterial document or doctrinal teaching of the Catholic Church, but is a reflection prepared by the Commission for Religious Relations with the Jews on current theological questions that have developed since the Second Vatican Council. It is intended to be a starting point for further theological thought with a view to enriching and intensifying the theological dimension of Jewish-Catholic dialogue.

\section{A brief history of the impact of "Nostra aetate" (No.4) over the last 50 years $^{2}$}

1. "Nostra aetate" (No.4) is rightly counted among those documents of the Second Vatican Council which have been able to effect, in a particularly striking manner, a new direction of the Catholic Church since then. ${ }^{3}$ This shift in the rela-

\footnotetext{
${ }^{2}$ Cardinal Kurt Koch has previously set forth this history in addresses on May 16, 2012 and Oct 29, 2012, which significantly inform this section of "Gifts and Calling."

3 - "Nostra Aetate is not a political document but a strictly religious and theological one. It also deserves mention that this new perspective of the relationship between Christianity and Judaism is not simply a secondary question but one that touches on the essential identity of the church itself, which becomes apparent also in the fact that it was also accorded a place in important constitutions of the Second Vatican Council. With regard to the reception history of conciliar documents, one can without doubt dare to assert that Nostra Aetate is to be reckoned among those conciliar texts which have in a convincing manner been able to effect a fundamental reorientation of the Second Vatican Council" (Koch, 2015).

- "[T]the old theory of substitution is gone since II Vatican Council. For us Christians today the covenant with the Jewish people is a living heritage, a living reality. There cannot be a mere coexistence between the two covenants" (Kasper, 2001, §3).

- "The teaching of the Second Vatican Council has represented for Catholics a clear landmark to which constant reference is made in our attitude and our relations with the Jewish people, marking a new and significant stage. The Council gave a strong impetus to our irrevocable commitment to pursue the path of dialogue, fraternity and friendship, a journey which has been deepened and developed in the last forty years, through important steps and significant gestures" (Benedict XVI, 2010, §2).
} 
tions of the Church with the Jewish people and Judaism becomes apparent only when we recall that there were previously great reservations on both sides, in part because the history of Christianity has been seen to be discriminatory against Jews, even including attempts at forced conversion (cf. "Evangelii gaudium", 248). ${ }^{4}$ The background of this complex connection consists inter alia in an asymmetrical relationship: as a minority the Jews were often confronted by and dependent upon a Christian majority. The dark and terrible shadow of the Shoah over Europe during the Nazi period led the Church to reflect anew on her bond with the Jewish people. ${ }^{5}$

2. The fundamental esteem for Judaism expressed in "Nostra aetate" (No.4), however, has enabled communities that once faced one another with skepticism to become - step by step over the years - reliable partners and even good friends, capable of weathering crises together and negotiating conflicts positively. Therefore, the fourth article of "Nostra aetate" is recognized as the solid foundation for improving the relationship between Catholics and Jews. ${ }^{6}$

3. For the practical implementation of "Nostra aetate" (No.4), Blessed Pope Paul VI on 22 October 1974 established the Commission for Religious Relations with the Jews which, although organizationally attached to the Pontifical Council for Promoting Christian Unity, is operationally independent and entrusted with the task of accompanying and fostering religious dialogue with Judaism. From a theological perspective it also makes good sense to link this Commission with the Council for Promoting Christian Unity, since the separation between Synagogue and Church may be viewed as the first and most far-reaching breach among the chosen people. ${ }^{7}$

- "Deserving of special gratitude to God is the veritable transformation of Christian-Jewish relations in these 50 years. Indifference and opposition have changed into cooperation and benevolence. From enemies and strangers, we have become friends and brothers. The Council, with the Declaration Nostra Aetate, has indicated the way: "yes" to rediscovering Christianity's Jewish roots; "no" to every form of anti-Semitism and blame for every wrong, discrimination and persecution deriving from it. Knowledge, respect and esteem for one another are the way" (Francis, 2015).

4 "Dialogue and friendship with the children of Israel are part of the life of Jesus' disciples. The friendship which has grown between us makes us bitterly and sincerely regret the terrible persecutions which they have endured, and continue to endure, especially those that have involved Christians" (Francis, 2014, §248).

5 "But it may be asked whether the Nazi persecution of the Jews was not made easier by the antiJewish prejudices imbedded in some Christian minds and hearts. Did anti-Jewish sentiment among Christians make them less sensitive, or even indifferent, to the persecution launched against the Jews by National Socialism when it reached power?" (CRRJ, 1998, §IV).

- "Nostra Aetate is considered the 'foundation document' and the 'Magna Carta' of the dialogue of the Roman Catholic Church with Judaism" (Koch, Oct 29, 2012), §1. See also Koch, May 16, 2012, $\S 1$.

- "[B]efore the recent crimes of the Nazi regime and, in general, with a retrospective look at a long and difficult history, it was necessary to evaluate and define in a new way the relationship between the Church and the faith of Israel" (Benedict XVI, 2005).

7 - "It also makes good sense from a theological point of view to combine this Commission with the Council for Promoting Christian Unity, since the separation of Church and Synagogue can be consid- 
4. Within a year of its foundation, the Holy See's Commission published its first official document on 1 December 1974, with the title "Guidelines and Suggestions for Implementing the Conciliar Declaration Nostra Aetate (No.4)". The crucial and new concern of this document consists in becoming acquainted with Judaism as it defines itself, giving expression to the high esteem in which Christianity holds Judaism and stressing the great significance for the Catholic Church of dialogue with the Jews, as stated in the words of the document: "On the practical level in particular, Christians must therefore strive to acquire a better knowledge of the basic components of the religious tradition of Judaism: they must strive to learn by what essential traits the Jews define themselves in the light of their own religious experience" (Preamble). On the basis of the Church's witness of faith in Jesus Christ, the document reflects upon the specific nature of the Church's dialogue with Judaism. Reference is made in the text to the roots of Christian liturgy in its Jewish matrix, new possibilities are outlined for rapprochement in the spheres of teaching, education and training, and finally suggestions are made for joint social action.

5. Eleven years later on 24 June 1985, the Holy See's Commission issued a second document entitled "Notes on the correct way to present the Jews and Judaism in preaching and catechesis in the Roman Catholic Church". This document has a stronger theological-exegetical orientation insofar as it reflects on the relationship of the Old and New Testaments, delineates the Jewish roots of the Christian faith, explicates the manner in which 'the Jews' are represented in the New Testament, points out commonalities in liturgy, above all in the great festivals of the church year, and briefly focuses on the relationship of Judaism and Christianity in history. With regard to the "land of the forefathers" the document emphasizes: "Christians are invited to understand this religious attachment which finds its roots in Biblical tradition, without however making their own any particular religious interpretation of this relationship.... The existence of the State of Israel and its political options should be envisaged not in a perspective which is in itself religious, but in their reference to the common principles of international law." The permanence of Israel is however to be perceived as an "historic fact and a sign to be interpreted within God's design" (VI, 1). ${ }^{8}$

ered the first schism in the history of the church, or as the Catholic theologian Erich Przywara has called it, the 'primal rift'...." (Koch May 16, 2012, §2).

- "The problem is not only the relationship of the Old and New Covenants, but the different problem of the relationship of post-biblical rabbinic and Talmudic Judaism-which arose only after the destruction of the Second Temple in the year 70 c.e.-with the church....The schism between Judaism and Christianity that continues until today is already clearly discernible in the Fourth Gospel with, on the one hand, the exclusion of Christians from the synagogue (John 9:22; 16:2), and on the other hand, the polemics of the Christians against "the Jews' (John 5:16, 18; 7:1. etc.)" (Kasper, "Foreword," xiv-xv).

${ }^{8}$ - "Since the foundation of the State of Israel in 1948, the Catholic Church sees itself confronted in the Holy Land with the reality that it has to develop its pastoral life within a state which decidedly understands itself as Jewish. Israel is the only land in the world with a majority Jewish population, and for that reason alone the Christians living there must necessarily engage in dialogue with them. In this regard the Holy See has consistently pursued two goals, that is, enabling on the one hand unhin- 
6. A third document of the Commission for Religious Relations with the Jews was presented to the public on 16 March 1998. It deals with the Shoah under the title "We remember. A reflection on the Shoah". This text delivers the harsh but accurate judgment that the balance of the 2000-year relationship between Jews and Christians is regrettably negative. It recalls the attitude of Christians towards the anti-Semitism of the National Socialists and focuses on the duty of Christians to remember the human catastrophe of the Shoah. In a letter at the beginning of this declaration Saint Pope John Paul II expresses his hope that this document will truly "help to heal the wounds of past misunderstandings and injustices. May it enable memory to play its necessary part in the process of shaping a future in which the unspeakable iniquity of the Shoah will never again be possible."

7. In the series of documents issued by the Holy See, reference must be made to the text published by the Pontifical Biblical Commission on 24 May 2001, which deals explicitly with Jewish-Catholic dialogue: "The Jewish People and their Sacred Scriptures in the Christian Bible". This represents the most significant exegetical and theological document of the Jewish-Catholic dialogue and is a treasure-trove of common issues which have their basis in the Scriptures of Judaism and Christianity. The Sacred Scriptures of the Jewish people are considered a "fundamental component of the Christian Bible", the fundamental themes of the

dered pastoral activity of the Catholic congregations in the Holy Land, and on the other, free access to the sacred sites of Christians for Christian pilgrims. That requires in the first instance political dialogue with the ruling executive of the State of Israel, which from the Jewish perspective must naturally always be embedded in a dialogue with the religious authorities of Judaism. Christians seem to be rather inclined to differentiate and delimit political and religious affairs from one another, while Judaism strives to converge and integrate the two dimensions" (Koch, May 16, 2012, §1).

- "In dialogue with Christians, Jews have explained that they do not consider themselves as a church, a sect, or a denomination, as is the case among Christian communities, but rather as a peoplehood that is not solely racial, ethnic or religious, but in a sense a composite of all these. It is for such reasons that an overwhelming majority of Jews see themselves bound in one way or another to the land of Israel. Most Jews see this tie to the land as essential to their Jewishness. Whatever difficulties Christians may experience in sharing this view they should strive to understand this link between land and people which Jews have expressed in their writings and worship throughout two millennia as a longing for the homeland, holy Zion. Appreciation of this link is not to give assent to any particular religious interpretation of this bond. Nor is this affirmation meant to deny the legitimate rights of other parties in the region, or to adopt any political stance in the controversies over the Middle East, which lie beyond the purview of this statement" (NCCB, 1975).

- [In response to an interviewer's question as to whether one must acknowledge that the founding of the State of Israel is a fulfillment of biblical land promises:] "That is a very difficult question. The question of the relationship between the biblical promise of land and its fulfillment in the state of Israel in 1948 has, on the one hand a theological significance and, on the other, a political one. It is true that the promise of land is an integral part of Israel's identity. But a distinction must be drawn between the promise and its realization. Palestinian Christians would contradict you vehemently here. They have experienced the Israeli seizure of land as the Nakba, as a disaster, which has often resulted in loss of the old homeland through flight and expulsion. This is understandable. It is essential to distinguish between the promise and the way it has been realized politically. They have experienced the latter as an event which was an injustice to them and which involved violence. And so one can understand why Palestinian Christians are not able to embrace a theological interpretation of the founding of the state of Israel. Moreover, the Palestinians also have a right to their own state" (Koch, 2013). 
Holy Scripture of the Jewish people and their adoption into the faith in Christ are discussed, and the manner in which Jews are represented in the New Testament is illustrated in detail.

8. Texts and documents, as important as they are, cannot replace personal encounters and face-to-face dialogues. ${ }^{9}$ While under Blessed Pope Paul VI the first steps in Jewish-Catholic dialogue were undertaken, Saint Pope John Paul II succeeded in fostering and deepening this dialogue through compelling gestures towards the Jewish people. He was the first pope to visit the former concentration camp of Auschwitz-Birkenau to pray for the victims of the Shoah, and he visited the Roman Synagogue to express his solidarity with the Jewish community. In the context of an historical pilgrimage to the Holy Land, he was also a guest of the state of Israel where he participated in interreligious encounters, paid a visit to both Chief Rabbis and prayed at the Western Wall. Again and again he met with Jewish groups, whether in the Vatican or during his numerous apostolic journeys. So too Benedict XVI, even before his election to the papacy, engaged in JewishCatholic dialogue by offering in a series of lectures important theological reflections on the relationship between the Old and the New Covenant, and the Synagogue and the Church. Following his election and in the footsteps of Saint Pope John Paul II he fostered this dialogue in his own way by reinforcing the same gestures and giving expression to his esteem for Judaism through the power of his words. As Archbishop of Buenos Aires, Cardinal Jorge Mario Bergoglio was greatly committed to fostering Jewish-Catholic dialogue and had many friends among the Jews of Argentina. Now as Pope he continues, at the international level, to intensify dialogue with Judaism through many friendly encounters. One of his first such encounters was in May 2014 in Israel, where he met with the two Chief Rabbis, visited the Western Wall, and prayed for the victims of the Shoah in Yad Vashem.

9. Even before the establishment of the Holy See's Commission, there were contacts and links with various Jewish organizations through the then Secretariat for Promoting Christian Unity. Since Judaism is multi-facetted and not constituted as an organizational unity, the Catholic Church was faced with the challenge of determining with whom to engage, because it was not possible to conduct individual and independent bilateral dialogues with all Jewish groupings and organizations which had declared their readiness to dialogue. To resolve this problem the Jewish organizations took up the suggestion of the Catholic Church to establish a single organization for this dialogue. The International Jewish Committee on Interreligious Consultations (IJCIC) is the official Jewish representative to the Holy See's Commission for Religious Relations with the Jews.

\footnotetext{
9 "Texts and documents, as important as they are, cannot replace personal encounters and dialogues face to face" (Koch, May 16, 2012, §3).
} 
10. The IJCIC began its work in 1970, and a year later the first joint conference was organized in Paris. The conferences which have been conducted regularly since are the responsibility of the entity known as the International CatholicJewish Liaison Committee (ILC), and they shape the collaboration between the IJCIC and the Holy See's Commission. In February 2011, once more in Paris, the ILC was able to look back with gratitude on 40 years of institutional dialogue. Much has developed over the past 40 years; the former confrontation has turned into successful cooperation, the previous potential for conflict has become positive conflict management, and the past co-existence marked by tension has been replaced by resilient and fruitful mutuality. The bonds of friendship forged in the meantime have proved to be stable, so that it has become possible to address even controversial subjects together without the danger of permanent damage being done to the dialogue. This was all the more necessary because over the past decades the dialogue had not always been free of tensions. ${ }^{10}$ In general, however, one can observe with appreciation that in Jewish-Catholic dialogue since the new millennium above all, intensive efforts have been made to deal openly and positively with any arising differences of opinion and conflicts, in such a way that mutual relations have become stronger.

11. Beside the dialogue with the IJCIC we should also mention the institutional conversation with the Chief Rabbinate of Israel, which is clearly to be seen as a fruit of the encounter of Saint Pope John Paul II with both Chief Rabbis in Jerusalem during his visit to Israel in March 2000. The first meeting was organized in June 2002 in Jerusalem, and since then such meetings have been conducted annually, taking place in Rome and Jerusalem alternately. The two delegations are relatively small so that a very personal and intensive discussion on various subjects is possible, such as on the sanctity of life, the status of the family, the significance of the Sacred Scriptures for life in society, religious freedom, the ethical foundations of human behavior, the ecological challenge, the relationship of secular and religious authority and the essential qualities of religious leadership in secular society. The fact that the Catholic representatives taking part in the meetings are bishops and priests and the Jewish representatives almost exclusively rabbis permits individual topics to be examined from a religious perspective as well. The dialogue with the Chief Rabbinate of Israel has to that extent enabled more open relations between Orthodox Judaism and the Catholic Church at a global level. After each meeting a joint declaration is published which in each instance has testified to the richness of the common spiritual heritage of Judaism and Christianity and to what valuable treasures are still to be unearthed. In reviewing over more than ten years of dialogue we can gratefully affirm that a strong friendship has resulted which represents a firm foundation for the future.

\footnotetext{
10 "The bonds of friendship forged in the meantime have proved to be stable, so that it has become possible to tackle even controversial subjects together without the danger of permanent damage being done to the dialogue. This was all the more necessary because over the past decades the dialogue had not always been free of tensions" (Koch, May 16, 2012, §3. Cf. Oct 29, 2012, §3).
} 
12. The efforts of the Holy See's Commission for Religious Relations with the Jews cannot of course be restricted to these two institutional dialogues. The Commission aims in fact at being open to all streams within Judaism and at maintaining contact with all Jewish groupings and organizations that wish to establish links with the Holy See. The Jewish side shows a particular interest in audiences with the Pope, which are in every instance prepared by the Commission. Besides direct contacts with Judaism the Holy See's Commission also strives to provide opportunities within the Catholic Church for dialogue with Judaism and to work together with individual Bishops' Conferences to support them locally in promoting Jewish-Catholic dialogue. The introduction of the 'Day of Judaism' in some European countries is a good example of this.

13. Over the past decades both the 'dialogue ad extra' and the 'dialogue ad intra $^{11}$ have led with increasing clarity to the awareness that Christians and Jews are irrevocably inter-dependent, ${ }^{12}$ and that the dialogue between the two is not a matter of choice but of duty as far as theology is concerned. Jews and Christians can enrich one another in mutual friendship. Without her Jewish roots the Church would be in danger of losing its soteriological anchoring in salvation history and would slide into an ultimately unhistorical Gnosis. ${ }^{13}$ Pope Francis states that "while it is true that certain Christian beliefs are unacceptable to Judaism, and that the Church cannot refrain from proclaiming Jesus as Lord and Messiah, there exists as well a rich complementarity which allows us to read the texts of the Hebrew Scriptures together and to help one another to mine the riches of God's

\footnotetext{
11 "The first dimension of this dialogue, that is, the meeting between the people of God of the Old Covenant, never revoked by God [cf. Rom. 11:29], and that of the New Covenant, is at the same time a dialogue within our Church, that is to say, between the first and the second part of her Bible" (John Paul II, 1980, §3. See also John Paul II, 1986, §4).

12 "The church is thus not simply a branch, a fruit or an offshoot of Israel. On the other hand, the church must draw its vigor and strength from the rootstock of Israel. If the engrafted branches are cut off from the root, they become withered, weak and eventually die. Thus, cutting itself off from its Jewish roots for centuries weakened the church, a weakness that became evident in the altogether too feeble resistance against the persecution of Jews. But the reverse is also true. Without the engrafted branches the root remains a barren stump. The engrafted branches give the root stock new vitality and fertility....Israel without the church is in danger of becoming too particularistic and reclusive, while the church without Israel, as the example of Marcionism makes clear, is in danger of losing its historical grounding and becoming ahistorical and Gnostic" (Kasper, "Foreword," xvi).

13 - "[T] vation and degenerating into an ultimately unhistorical gnosis. By the same token, Jews could with regard to the Abrahamic covenant arrive at the insight that Israel without the church would be in danger of remaining too particularist. In this fundamental sense Israel and the church remain bound up with one another according to the covenant and interdependent on one another" (Koch, 2011, §2b).

- "Naturally I do not have the right to judge what Judaism may gain from this dialogue for its own purposes. I can only join Cardinal Walter Kasper in expressing the wish that it recognize that 'separating Judaism from Christianity' would mean 'robbing it of its universality,' which was already promised to Abraham. For the Christian church however it is certainly true that without Judaism it is in danger of losing its location with salvation history and in the end declining into an unhistorical Gnosis” (Koch, Oct 29, 2012, §5. See also Koch, May 16, 2012, §3 and Koch, May 24, 2012).
} 
word. We can also share many ethical convictions and a common concern for justice and the development of peoples" ("Evangelii gaudium", 249).

\section{The special theological status of Jewish-Catholic dialogue}

14. The dialogue with Judaism is for Christians something quite special, since Christianity possesses Jewish roots which determine relations between the two in a unique way (cf. "Evangelii gaudium", 247). ${ }^{14}$ In spite of the historical breach and the painful conflicts arising from it, the Church remains conscious of its enduring continuity with Israel. Judaism is not to be considered simply as another religion; the Jews are instead our "elder brothers" (Saint Pope John Paul II), ${ }^{15}$ our "fathers in faith" (Benedict XVI). ${ }^{16}$ Jesus was a Jew, was at home in the Jewish tradition of his time, and was decisively shaped by this religious milieu ${ }^{17}$ (cf. "Ecclesia in Medio Oriente", 20). ${ }^{18}$ His first disciples gathered around him had the same heritage and were defined by the same Jewish tradition in their everyday life. In his unique relationship with his heavenly Father, Jesus was intent above all on proclaiming the coming of the Kingdom of God. "The time is fulfilled and the kingdom of God is at hand, repent and believe in the gospel" (Mk 1:15). Within Judaism there were many very different kinds of ideas regarding how the kingdom of God would be realized, and yet Jesus' central message on the Kingdom of God is in accordance with some Jewish thinking of his day. One cannot understand Jesus' teaching or that of his disciples without situating it within the

\footnotetext{
14 "We hold the Jewish people in special regard because their covenant with God has never been revoked, for 'the gifts and the call of God are irrevocable' (Rom 11:29). The Church, which shares with Jews an important part of the sacred Scriptures, looks upon the people of the covenant and their faith as one of the sacred roots of her own Christian identity (cf. Rom 11:16-18). As Christians, we cannot consider Judaism as a foreign religion; nor do we include the Jews among those called to turn from idols and to serve the true God (cf. 1 Thes 1:9). With them, we believe in the one God who acts in history, and with them we accept his revealed word" (Francis, 2014, §247).

15 'The Jewish religion is not 'extrinsic' to us, but in a certain way is 'intrinsic' to our own religion. With Judaism therefore we have a relationship which we do not have with any other religion. You are our dearly beloved brothers and, in a certain way, it could be said that you are our elder brothers" (John Paul II, 1986, §4).

16 "From the earliest days of Christianity, our identity and every aspect of our life and worship have been intimately bound up with the ancient religion of our fathers in faith" (Benedict XVI, Feb 12, 2009).

17 "Jesus' human identity is determined on the basis of his bond with the people of Israel, with the dynasty of David and his descent from Abraham. And this does not mean only a physical belonging. By taking part in the synagogue celebrations where the Old Testament texts were read and commented on, Jesus also came humanly to know these texts; he nourished his mind and heart with them, using them in prayer and as an inspiration for his actions. Thus he became an authentic son of Israel, deeply rooted in his own people's long history" (John Paul II, 1997, §3).

18 "Jesus, a son of the Chosen People, was born, lived and died a Jew (cf. Rom 9:4-5). Mary, his Mother, likewise invites us to rediscover the Jewish roots of Christianity. These close bonds are a unique treasure of which Christians are proud and for which they are indebted to the Chosen People. The Jewishness of the Nazarene allows Christians to taste joyfully the world of the Promise and resolutely introduces them into the faith of the Chosen People, making them a part of that People. Yet the person and the deepest identity of Jesus also divide them, for in him Christians recognize the Messiah, the Son of God" (Benedict XVI, 2012, §20).
} 
Jewish horizon in the context of the living tradition of Israel; one would understand his teachings even less so if they were seen in opposition to this tradition. ${ }^{19}$ In Jesus not a few Jews of his time saw the coming of a 'new Moses', the promised Christ (Messiah). But his coming nevertheless provoked a drama with consequences still felt today. Fully and completely human, a Jew of his time, descendant of Abraham, son of David, shaped by the whole tradition of Israel, heir of the prophets, Jesus stands in continuity with his people and its history. On the other hand he is, in the light of the Christian faith, himself God - the Son - and he transcends time, history, and every earthly reality. The community of those who believe in him confesses his divinity (cf. Phil 2:6-11). In this sense he is perceived to be in discontinuity with the history that prepared his coming. From the perspective of the Christian faith, he fulfills the mission and expectation of Israel in a perfect way. At the same time, however, he overcomes and transcends them in an eschatological manner. ${ }^{20}$ Herein consists the fundamental difference between Judaism and Christianity, that is, how the figure of Jesus is to be evaluated. Jews are able to see Jesus as belonging to their people, a Jewish teacher who felt himself called in a particular way to preach the Kingdom of God. That this Kingdom of God has come with himself as God's representative is beyond the horizon of Jewish expectation. The conflict between Jesus and the Jewish authorities of his time is ultimately not a matter of an individual transgression of the law, but of Jesus' claim to be acting with divine authority. The figure of Jesus thus is and remains for Jews the 'stumbling block', the central and neuralgic point in JewishCatholic dialogue. From a theological perspective, Christians need to refer to the Judaism of Jesus' time and to a degree also the Judaism that developed from it over the ages for their own self-understanding. Given Jesus' Jewish origins, coming to terms with Judaism in one way or another is indispensable for Christians.

\footnotetext{
19 "Jesus was and always remained a Jew...Jesus is fully a man of his time, and of his environmentthe Jewish Palestinian one of the first century, the anxieties and hopes of which he shared....Jesus shares, with the majority of Palestinian Jews of that time, some pharisaic doctrines: the resurrection of the body; forms of piety, like aims-giving, prayer, fasting (Mt. 6:1-18) and the liturgical practice of addressing God as Father; the priority of the commandment to love God and our neighbor (Mk. 12:28-34)" (CCJR, 1985, §§12, 17).

${ }^{20}$ - "Furthermore, in underlining the eschatological dimension of Christianity we shall reach a greater awareness that the people of God of the Old and the New Testament are tending towards a like end in the future: the coming or return of the Messiah - even if they start from two different points of view. It is more clearly understood that the person of the Messiah is not only a point of division for the people of God but also a point of convergence" (CRRJ, 1985, II, 10).

- "What has already been accomplished in Christ must yet be accomplished in us and in the world. The definitive fulfillment will be at the end with the resurrection of the dead, a new heaven and a new earth. Jewish messianic expectation is not in vain. It can become for us Christians a powerful stimulant to keep alive the eschatological dimension of our faith. Like them, we too live in expectation. The difference is that for us the One who is to come will have the traits of the Jesus who has already come and is already present and active among us" (PBC, 2001, §21).

- "But whilst Jews expect the coming of the Messiah, who is still unknown, Christians believe that he has already shown his face in Jesus of Nazareth whom we as Christians therefore confess as the Christ, he who at the end of time will be revealed as the Messiah for Jews and for all nations" (Kasper, 2002, III).
} 
Yet, the history of the relationship between Judaism and Christianity has also been mutually influenced over time.

15. Dialogue between Jews and Christians then can only be termed 'interreligious dialogue' by analogy, that is, dialogue between two intrinsically separate and different religions. It is not the case that two fundamentally diverse religions confront one another after having developed independently of one another or without mutual influence. ${ }^{21}$ The soil that nurtured both Jews and Christians is the Judaism of Jesus' time, which not only brought forth Christianity but also, after the destruction of the temple in the year 70, post-biblical rabbinical Judaism which then had to do without the sacrificial cult and, in its further development, had to depend exclusively on prayer and the interpretation of both written and oral divine revelation. Thus Jews and Christians have the same mother and can be seen, as it were, as two siblings who-as is the normal course of events for siblings-have developed in different directions ${ }^{22}$. The Scriptures of ancient Israel constitute an integral part of the Scriptures of both Judaism and Christianity, understood by both as the word of God, revelation, and salvation history. The first Christians were Jews; as a matter of course they gathered as part of the community in the Synagogue, they observed the dietary laws, the Sabbath and the requirement of circumcision, while at the same time confessing Jesus as the Christ, the Messiah sent by God for the salvation of Israel and the entire human race. With Paul the 'Jewish Jesus movement' definitively opens up other horizons and transcends its purely Jewish origins. Gradually his concept came to prevail, that is, that a non-Jew did not have to become first a Jew in order to confess Christ. In the early years of the Church, therefore, there were the so-called Jewish Christians and the Gentile Christians, the ecclesia ex circumcisione and the ecclesia ex gentibus, one Church originating from Judaism, the other from the

\footnotetext{
21 - "One people of God, not two peoples of God: Speaking literally rather than metaphorically, this means that Israel and the church are related to and interdependent on one another, precisely because they exist in a state not only of unity but also difference. Israel and the church thus remain bound up with one another to that extent, and indeed both unmixed yet undivided....Speaking of the one people of God however proves to be difficult because this single people of God lives in separated communities. It may therefore be most appropriate in regard to Israel and the church to speak of the one people of God's covenant, which however lives in two parts in a state of division" (Koch, 2011, §2c).

- "[P]ost-biblical Judaism and the church are not two covenant peoples: they are the one covenant people.....Between Judaism and Christianity, therefore, is a differentiation that is neither simply a parallel coexistence, nor an opposition....[T]he two are dialectically related to each other in their difference" (Kasper, "Foreword," xv).

- "[I]n underlining the eschatological dimension of Christianity we shall reach a greater awareness that the people of God [note singular] of the Old and the New Testament are tending towards a like end in the future: the coming or return of the Messiah--even if they start from two different points of view" (CCJR, "Notes" (1985), §II, 10).]

22 "The problem is not only the relationship of the Old and New Covenant, but the different problem of the relationship of post-biblical Rabbinic and Talmudic Judaism-which arose only after the destruction of the Second Temple in the year A.D. 70-with the church. The canons and structures of both formed in parallel. Therefore the New Testament can give us no clear and above all no uniform answer to the question just posed. Paul wrestled with it again and again, but in a sense, the situation was still open in his lifetime" (Kasper, "Foreword," iv).
} 
Gentiles, who however together constituted the one and only Church of Jesus Christ.

16. The separation of the Church from the Synagogue does not take place abruptly however and, according to some recent insights, may not have been complete until well into the third or fourth centuries. ${ }^{23}$ This means that many Jewish Christians of the first period did not perceive any contradiction between living in accordance with some aspects of the Jewish tradition and yet confessing Jesus as the Christ. Only when the number of Gentile Christians represented the majority, and within the Jewish community the polemics regarding the figure of Jesus took on sharper contours, did a definitive separation appear to be no longer avoidable. Over time the siblings Christianity and Judaism increasingly grew apart, becoming hostile and even defaming one another. For Christians, Jews were often represented as damned by God and blind since they were unable to recognize in Jesus the Messiah and bearer of salvation. For Jews, Christians were often seen as heretics who no longer followed the path originally laid down by God but who went their own way. It is not without reason that in the Acts of the Apostles Christianity is called 'the way' (cf. Acts 9:2; 19:9, 23; 24:14,22) in contrast to the Jewish Halacha which determined the interpretation of the law for practical conduct. Over time Judaism and Christianity became increasingly alienated from one another, even becoming involved in ruthless conflicts and accusing one another of abandoning the path prescribed by God.

17. On the part of many of the Church Fathers the so-called replacement theory or supersessionism steadily gained favor until in the Middle Ages it represented the standard theological foundation of the relationship with Judaism: the promises and commitments of God would no longer apply to Israel because it had not recognized Jesus as the Messiah and the Son of God, but had been transferred to the

\footnotetext{
23 - "Even though contemporary research tends to accept that the process of estrangement and dissociation between Judaism and Christianity extended over a longer period than previously assumed and surely only gradually took shape during the second century after the destruction of the second temple in A.D. 70, there is nevertheless no question that this process was set in place at the very beginning of Jewish-Christian relations, and the relationship between Jews and Christians was marked by conflicts already at an early stage....[T]he relationship between Jews and Christians has deteriorated progressively as the awareness of belonging to the same family was gradually lost. It has therefore in the course of history been exposed to great strain and hostility, which have in many cases unfortunately led to anti-Jewish attitudes involving outbreaks of violence and pogroms against the Jews" (Koch, 2015).

- "As historical research has shown, the process of alienation took place less quickly than had long been assumed. But the process entailed ever more radical consequences. The idea that the Church had superseded Judaism came to prevail. Saint Paul's Epistle to the Romans, which very subtly considers the mystery of the interleaving of the New and Old Covenants, was also not able to prevent this. Even today it is a major theological challenge to consider how the eternal validity of the Old Covenant can be reconciled with the newness of the New Covenant in Jesus Christ" (Koch, 2013).

- "By the third century, however, a de-Judaizing process had set in which tended to undervalue the Jewish origins of the Church, a tendency that has surfaced from time to time in devious ways throughout Christian history" (NCCB, 1975).
} 
Church of Jesus Christ which was now the true 'new Israel', the new chosen people of God. ${ }^{24}$ Arising from the same soil, Judaism and Christianity in the centuries after their separation became involved in a theological antagonism which was only to be defused at the Second Vatican Council. With its Declaration "Nostra aetate" (No.4) the Church unequivocally professes, within a new theological framework, the Jewish roots of Christianity. While affirming salvation through an explicit or even implicit faith in Christ, the Church does not question the continued love of God for the chosen people of Israel. A replacement or supersession theology which sets against one another two separate entities, a Church of the Gentiles and the rejected Synagogue whose place it takes, is deprived of its foundations. From an originally close relationship between Judaism and Christianity a long-term state of tension had developed, which has been gradually transformed after the Second Vatican Council into a constructive dialogue relationship.

18. There have often been attempts to identify this replacement theory in the Epistle to the Hebrews. This Epistle, however, is not directed to the Jews but rather to the Christians of Jewish background who have become weary and uncertain. ${ }^{25}$ Its purpose is to strengthen their faith and to encourage them to persevere, by pointing to Christ Jesus as the true and ultimate high priest, the mediator of the new covenant. This context is necessary to understand the Epistle's contrast between the first purely earthly covenant and a second better (cf. Heb 8:7) and new covenant (cf. 9:15, 12:24). The first covenant is defined as outdated, in decline and doomed to obsolescence (cf. 8:13), while the second covenant is defined as everlasting (cf. 13:20). To establish the foundations of this contrast the Epistle refers to the promise of a new covenant in the Book of the Prophet Jeremiah 31:31-34 (cf. Heb 8:8-12). This demonstrates that the Epistle to the Hebrews has no intention of proving the promises of the Old Covenant to be false, but on the contrary treats them as valid. The reference to the Old Testament promises is intended to help Christians to be sure of their salvation in Christ. At issue in the Epistle to the Hebrews is not the contrast of the Old and New Covenants as we understand them today, nor a contrast between the church and Judaism. Rather, the contrast is between the eternal heavenly priesthood of Christ and the transitory earthly priesthood. ${ }^{26}$ The fundamental issue in the Epistle to the

\footnotetext{
24 - "Much of the alienation between Christian and Jew found its origins in a certain anti-Judaic theology which over the centuries has led not only to social friction with Jews but often to their oppression" (NCCB, 1975).

- "There can be no denial of the fact that from the time of the Emperor Constantine on, Jews were isolated and discriminated against in the Christian world. There were expulsions and forced conversions. Literature propagated stereotypes, preaching accused the Jews of every age of deicide; the ghetto which came into being in 1555 with a papal bull became in Nazi Germany the antechamber of the extermination" (Cassidy, 1998).

25 "There have often been attempts to locate this substitution theory in the Epistle to the Hebrews. But the Epistle to the Hebrews is not directed outwards to the Jews but within, to the Christians who have become weary and uncertain" (Kasper, 2004).

26 "Although a long-standing reading of Hebrews contends that it declares the Old Covenant to be obsolete and fading away (Heb 8:13), it would be anachronistic to project the distinction between
} 
Hebrews in the new situation is a Christological interpretation of the New Covenant. For exactly this reason, "Nostra aetate" (No.4) did not refer to the Epistle to the Hebrews, but rather to Saint Paul's reflections in his letter to the Romans 911 .

19. For an outside observer, the Conciliar Declaration "Nostra aetate" could give the impression that the text deals with the relations of the Catholic Church with all world religions in a relationship based on parity, but the history of its development and the text itself point in a different direction. Originally Saint Pope John XXIII proposed that the Council should promulgate a Tractatus de Iudaeis, but in the end the decision was made to give consideration to all world religions in "Nostra aetate". However, the fourth article of this Conciliar Declaration, which deals with a new theological relationship with Judaism, represents almost the heart of the document, in which a place is also made for the Catholic Church's relationship with other religions. ${ }^{27}$ The relationship with Judaism can in that sense be seen as the catalyst for the determination of the relationship with the other world religions. ${ }^{28}$

20. Nevertheless, from the theological perspective the dialogue with Judaism has a completely different character and is on a different level in comparison with the

Judaism and Christianity back already into the first century. This letter is written to the Hebrews and not possibly written against the Hebrews. So the text does not seek to devaluate Judaism as such, but questions the value of the Levitical priesthood and its sacrificial rites" (Kasper, "Foreword," xv).

27 - "[T]he question of the relationship of the Catholic Church to Judaism is considered [in Nostra aetate] within the broader context of the presentation of the relationship of the church to the nonChristian religions in general. To a certain extent that involves a compromise, since Judaism is for us Christians not just one among the many non-Christian religions, and the relationship between Judaism and Christianity must not be reduced to just another variant of interreligious dialogue so that its distinctive uniqueness is no longer brought to bear.

For the church has a unique and distinctive relationship with Judaism that it has with no other religion, and it cannot understand itself without reference to Judaism..." (Koch, 2015).

- "The way ahead was to become a thorny one. After the document had made its passage through the Council, Cardinal Bea told a friend: 'If I had known all the difficulties before, I do not know whether I would have had the courage to take this way.' There was vehement opposition both from outside and from within. From inside the old well-known patterns of traditional anti-Judaism emerged, from outside there was a storm of protest especially from Muslim countries with serious threats against the Christians living there as small minorities. In order to save the furniture from the burning house it was decided to integrate the envisaged Declaration as one chapter in the 'Declaration about the Non-Christian Religions.' to be known later as "Nostra aetate". Yet this was a compromise, for Judaism is not one religion among the non-Christian religions, but as the Chapter 4 of the Declaration made very clear, Christianity has a particular and a unique relation with Judaism" (Kasper, 2002, $\S \mathrm{I})$.

28 "Since 1965 many things have occurred. ... [T] he many encounters that at every level have made possible a respectful and blessed exchange: through these, rediscovering fraternity, we Catholics became aware with greater clarity that the faith of Israel is that of our elder brothers, and, most importantly, that Judaism is as a sacrament of every otherness that as such the Church must learn to discern, recognize and celebrate" (Kasper, 2002). 
other world religions. ${ }^{29}$ The faith of the Jews testified to in the Bible, found in the Old Testament, is not for Christians another religion but the foundation of their own faith, although clearly the figure of Jesus is the sole key for the Christian interpretation of the Scriptures of the Old Testament. The cornerstone of the Christian faith is Jesus (cf. Acts 4:11; 1 Pt 2:4-8). However, the dialogue with Judaism occupies a unique position for Christians; Christianity is by its roots connected with Judaism as with no other religion. Therefore the Jewish-Christian dialogue can only with reservations be termed 'interreligious dialogue' in the true sense of the expression ${ }^{30}$ one could however speak of a kind of 'intra-religious' or 'intra-familial' dialogue sui generis. In his address in the Roman Synagogue on 13 April 1986 Saint Pope John Paul II expressed this situation in these words: "The Jewish religion is not 'extrinsic' to us but in a certain way is 'intrinsic' to our own religion. With Judaism therefore we have a relationship which we do not have with any other religion. You are our dearly beloved brothers and, in a certain way, it could be said that you are our elder brothers."

\section{Revelation in history as 'Word of God' in Judaism and Christianity}

21. We find in the Old Testament God's plan of salvation presented for his people (cf. "Dei verbum", 14). This plan of salvation is expressed in an enlightening way at the beginning of biblical history in the call to Abraham (Gen 12ff). In order to reveal himself and speak to humankind, redeeming it from sin and gathering it together as one people, God began by choosing the people of Israel through Abraham and setting them apart. To them God revealed himself gradually through his emissaries, his prophets, as the true God, the only God, the living God, the redeeming God. This divine election was constitutive of the people of Israel. Only after the first great intervention of the redeeming God, the liberation from slavery in Egypt (cf. Ex 13:17ff) and the establishment of the covenant at Sinai (Ex 19ff), did the twelve tribes truly become a nation and become conscious of being the people of God, the bearers of his message and his promises, witnesses of his merciful favor in the midst of the nations and also for the nations (cf. Is $26: 1-9 ; 54 ; 60 ; 62)$. In order to instruct his people on how to fulfill their mission and how to pass on the revelation entrusted to them, God gave Israel the law which defines how they are to live (cf. Ex 20; Deut 5), and which distinguishes them from other peoples. ${ }^{31}$

\footnotetext{
29 "It is evident that, as Christians, our dialogue with the Jews is situated on a different level than that in which we engage with other religions" (Ratzinger, 2000).

30 "Christians today have an open ear for the world of religions and accordingly display a greater readiness for inter-religious dialogue. [A danger] exists in the fact that the relationship between Judaism and Christianity and between synagogue and church today is located within inter-religious dialogue, reducing it to the level of merely another variant of inter-religious conversation, so that its irreducible uniqueness is no longer brought to bear (Koch, 2011, §2).

31 "Here on Mount Sinai, the truth of 'who God is' became the foundation and guarantee of the covenant. Moses enters "the luminous darkness" (The Life of Moses, II, 164), and there he is given the law 'written with the finger of God' (Ex. 31:18). But what is this law? It is the law of life and freedom! At the Red Sea the people had experienced a great liberation. They had seen the power and fidelity of
} 
22. Like the Church itself even in our own day, Israel bears the treasure of its election in fragile vessels. The relationship of Israel with its Lord is the story of its faithfulness and its unfaithfulness. In order to fulfill his work of salvation despite the smallness and weakness of the instruments he chose, God manifested his mercy and the graciousness of his gifts, as well as his faithfulness to his promises which no human infidelity can nullify (cf. Rom 3:3; 2 Tim 2:13). At every step of his people along the way God set apart at least a 'small number' (cf. Deut 4:27), a 'remnant' (cf. Is 1:9; Zeph 3:12; cf. also Is 6:13; 17:5-6), a handful of the faithful who 'have not bowed the knee to Baal' (cf. 1 Kings 19:18). Through this remnant, God realized his plan of salvation. Constantly the object of his election and love remained the chosen people as through them - as the ultimate goal - the whole of humanity is gathered together and led to him. ${ }^{32}$

23. The Church is called the new people of God (cf. "Nostra aetate", No.4) but not in the sense that the people of God of Israel has ceased to exist. The Church "was prepared in a remarkable way throughout the history of the people of Israel and by means of the Old Covenant" ("Lumen gentium", 2). The Church does not replace the people of God of Israel, since as the community founded on Christ it represents in him the fulfillment ${ }^{33}$ of the promises made to Israel. This does not

God; they had discovered that he is the God who does indeed set his people free as he had promised. But now on the heights of Sinai this same God seals his love by making the covenant that he will never renounce. If the people obey his law, they will know freedom forever. The exodus and the covenant are not just events of the past; they are forever the destiny of all God's people!" (John Paul II, 2000, $\S 2)$.

32 - "Confessing the universal and therefore also exclusive mediation of salvation through Jesus Christ belongs to the core of Christian faith, as does the confession of the one God, the God of Israel, who through his revelation in Jesus Christ has become the God of all peoples, insofar as in him the promise has been fulfilled 'that the peoples will pray to the God of Israel as the one God, that the mountain of the Lord will be exalted above the other mountains' [quoting J. Ratzinger, Many Religions, One Covenant, 110]" (Koch, 2011, 2d).

- "Thus the church has spread universally among the nations the monotheism of Israel and the Ten Commandments as the core of the Mosaic law, and has thereby contributed to the fact that the promise given to Abraham that he would be a blessing to all nations (Gen. 12:3; 18:18, etc.) has come true" (Kasper, "Foreword," xvi).

33 ["'The Gifts and the Calling of God Are Irrevocable' (Rom 11:29)" does not explicitly define what it means by the terms "fulfill" and "fulfillment," though in $\$ 28$ (see previous note) it observes that the "ultimate goal" of the plan of salvation is for "the whole of humanity is gathered together and led to [God]." Also, in $\$ 35$ it states that "Confessing the universal and therefore also exclusive mediation of salvation through Jesus Christ belongs to the core of Christian faith. So too does the confession of the one God, the God of Israel, who through his revelation in Jesus Christ has become totally manifest as the God of all peoples, insofar as in him the promise has been fulfilled that all peoples will pray to the God of Israel as the one God (cf. Is 56:1-8)." In other words, through the church, Christ fulfills the promise to Abraham that he would be a blessing to all nations. Other post-Nostra aetate ecclesial documents discuss fulfillment with a more explicit futurist eschatology, as in the quotations below:]

- "When commenting on biblical tests, emphasis will be laid on the continuity of our faith with that of the earlier Covenant, in the perspective of the promises, without minimizing those elements of Christianity which are original. We believe that those promises were fulfilled with the first coming of Christ. But it is none the less true that we still await their perfect fulfillment in his glorious return at the end of time" (CRRJ, 1974, II). 
mean that Israel, not having achieved such a fulfillment, can no longer be considered to be the people of God. "Although the Church is the new people of God, the Jews should not be presented as rejected or accursed by God, as if this followed from the Holy Scriptures" ("Nostra aetate", No.4).

- "The notion of fulfillment is an extremely complex one, one that could easily be distorted if there is a unilateral insistence either on continuity or discontinuity. Christian faith recognizes the fulfillment, in Christ, of the Scriptures and the hopes of Israel, but it does not understand this fulfillment as a literal one. Such a conception would be reductionist. In reality, in the mystery of Christ crucified and risen, fulfillment is brought about in a manner unforeseen. It includes transcendence. Jesus is not confined to playing an already fixed role - that of Messiah — but he confers, on the notions of Messiah and salvation, a fullness which could not have been imagined in advance; he fills them with a new reality; one can even speak in this connection of a 'new creation'. It would be wrong to consider the prophecies of the Old Testament as some kind of photographic anticipations of future events. All the texts, including those which later were read as messianic prophecies, already had an immediate import and meaning for their contemporaries before attaining a fuller meaning for future hearers. The messiahship of Jesus has a meaning that is new and original....Insistence on discontinuity between both Testaments and going beyond former perspectives should not, however, lead to a one-sided spiritualization. What has already been accomplished in Christ must yet be accomplished in us and in the world. The definitive fulfillment will be at the end with the resurrection of the dead, a new heaven and a new earth. Jewish messianic expectation is not in vain. It can become for us Christians a powerful stimulus to keep alive the eschatological dimension of our faith. Like them, we too live in expectation. The difference is that for us the One who is to come will have the traits of the Jesus who has already come and is already present and active among us" (PBC, 2001, §21).

- "Typology further signifies reaching towards the accomplishment of the divine plan, when 'God will be all in all' (1 Cor. 15:28). This holds true also for the Church which, realized already in Christ, yet awaits its definitive perfecting as the Body of Christ. The fact that the Body of Christ is still tending towards its full stature (Eph. 4:12-19) takes nothing from the value of being a Christian. So also the calling of the patriarchs and Exodus from Egypt do not lose their importance and value in God's design from being at the same time intermediate stages (e.g., Nostra Aetate, no. 4)....Salvation and liberation are already accomplished in Christ and gradually realized by the sacraments in the Church. This makes way for the fulfillment of God's design, which awaits its final consummation with the return of Jesus as Messiah, for which we pray each day. The Kingdom, for the coming of which we also pray each day, will be finally established. With salvation and liberation the elect and the whole of Creation will be transformed in Christ (Rm. 8:19-23). Furthermore, in underlining the eschatological dimension of Christianity we shall reach a greater awareness that the people of God of the Old and the New Testament are tending towards a like end in the future: the coming or return of the Messiah-even if they start from two different points of view. It is more clearly understood that the person of the Messiah is not only a point of division for the people of God but also a point of convergence. Thus it can be said that Jews and Christians meet in a comparable hope, grounded on the same promise made to Abraham (Gn. 12:1-3; Heb. 6:13-18)" (CCJR, 1985, §§8-10).

- "The lectionary readings from the prophets are selected to bring out the ancient Christian theme that Jesus is the "fulfillment" of the biblical message of hope and promise, the inauguration of the 'days to come' .... This truth needs to be framed very carefully. Christians believe that Jesus is the promised Messiah who has come (see Lk 4:22), but also know that his messianic kingdom is not yet fully realized. The ancient messianic prophecies are not merely temporal predictions but profound expressions of eschatological hope. Since this dimension can be misunderstood or even missed altogether, the homilist needs to raise clearly the hope found in the prophets and heightened in the proclamation of Christ. This hope includes trust in what is promised but not yet seen. While the biblical prophecies of an age of universal shalom are 'fulfilled' (i.e., irreversibly inaugurated) in Christ's coming, that fulfillment is not yet completely worked out in each person's life or perfected in the world at large....Christians proclaim that the Messiah has indeed come and that God's Reign is 'at hand.' With the Jewish people, we await the complete realization of the messianic age" (BCL, 1988, $\S \S 11-12)$. 
24. God revealed himself in his Word, so that it may be understood by humanity in actual historical situations. This Word invites all people to respond. If their responses are in accord with the Word of God they stand in right relationship with him. For Jews this Word can be learned through the Torah and the traditions based on it. The Torah is the instruction for a successful life in right relationship with God. Whoever observes the Torah has life in its fullness (cf. Pirqe Avot II, 7). ${ }^{34}$ By observing the Torah the Jew receives a share in communion with God. In this regard, Pope Francis has stated: "The Christian confessions find their unity in Christ; Judaism finds its unity in the Torah. Christians believe that Jesus Christ is the Word of God made flesh in the world; ${ }^{35}$ for Jews the Word of God is present above all in the Torah. Both faith traditions find their foundation in the One God, the God of the Covenant, who reveals himself through his Word. In seeking a right attitude towards God, Christians turn to Christ as the fount of new life, and Jews to the teaching of the Torah." (Address to members of the International Council of Christians and Jews, 30 June 2015).

25. Judaism and the Christian faith as seen in the New Testament are two ways by which God's people can make the Sacred Scriptures of Israel their own. The Scriptures which Christians call the Old Testament is open therefore to both ways. ${ }^{36}$ A response to God's word of salvation that accords with one or the other tradition can thus open up access to God, even if it is left up to his counsel of salvation to determine in what way he may intend to save mankind in each instance. That his will for salvation is universally directed is testified by the Scriptures (cf. e.g. Gen $12: 1-3$; Is $2: 2-5 ; 1$ Tim 2:4). Therefore there are not two paths to salvation according to the expression "Jews hold to the Torah, Christians hold to Christ". Christian faith proclaims that Christ's work of salvation is universal and

\footnotetext{
${ }^{34}$ [The document never defines which of many possible definitions of "salvation" it prefers. This is also true of the Catechism of the Catholic Church, which perhaps comes close to doing so in its discussion of Adam and Eve: " [W] himself to our first parents from the very beginning' [citing Dei Verbum, §3; cf. Jn 1:13; Rom 1:1920]. He invited them to intimate communion with himself and clothed them with resplendent grace and justice.... 'After the fall [God] buoyed them up with the hope of salvation, by promising redemption;...For he wishes to give eternal life to all those who seek salvation by patience in well-doing' [citing Dei Verbum, §3; cf. Gen 3:15; Rom 2:6-7] (CCC, §§54-55)." The document's use in reference to the Torah of the phrases "right relationship [twice]," "life in its fullness' [cf. Johannine "eternal life" language in e.g., Jn 10:10], and "share in communion with God" all give the impression that because Jews are in covenant with a saving God, that they are "saved" by that intimate relationship. See also note 40.]

35 "Jesus understands himself as the Torah — as the word of God in person. The tremendous prologue of John's Gospel-'in the beginning was the Word, and the Word was with God, and the Word was God' (Jn 1:1) - says nothing different from what the Jesus of the Sermon on the Mount....The issue of Jesus' claim to be Temple and Torah in person also has implications for the question of Israel - the issue of the living community of the people in whom God's word is actualized" (Benedict XVI, 2007, 110-111).

36 "After centuries of antagonism, we now see it as our task to bring these two ways of rereading the biblical texts - the Christian way and the Jewish way-into dialogue with one another, if we are to understand God's will and his word aright" (Benedict XVI, 2011, 35).
} 
involves all mankind. God's word is one single and undivided reality which takes concrete form in each respective historical context.

26. In this sense, Christians affirm that Jesus Christ can be considered as 'the living Torah of God'. Torah and Christ are the Word of God, his revelation for us human beings as testimony of his boundless love. For Christians, the preexistence of Christ as the Word and Son of the Father is a fundamental doctrine, and according to rabbinical tradition the Torah and the name of the Messiah exist already before creation (cf. Genesis Rabbah 1, 1). Further, according to Jewish understanding God himself interprets the Torah in the Eschaton, while in Christian understanding everything is recapitulated in Christ in the end (cf. Eph 1:10; Col 1:20). In the gospel of Matthew Christ is seen as it were as the 'new Moses'. Matthew 5:17-19 presents Jesus as the authoritative and authentic interpreter of the Torah (cf. Lk 24:27, 45-47). In the rabbinical literature, however, we find the identification of the Torah with Moses. Against this background, Christ as the 'new Moses' can be connected with the Torah. Torah and Christ are the locus of the presence of God in the world as this presence is experienced in the respective worship communities. The Hebrew dabar means word and event at the same time - and thus one may reach the conclusion that the word of the Torah may be open for the Christ event.

\section{The relationship between the Old and New Testament and the Old and New Covenant}

27. The covenant that God has offered Israel is irrevocable. "God is not man, that he should lie" (Num 23:19; cf. 2 Tim 2:13). The permanent elective fidelity of God expressed in earlier covenants is never repudiated (cf. Rom 9:4; 11:1-2). The New Covenant does not revoke the earlier covenants, but it brings them to fulfillment. Through the Christ event Christians have understood that all that had gone before was to be interpreted anew. For Christians the New Covenant has acquired a quality of its own, even though the orientation for both consists in a unique relationship with God (cf. for example, the covenant formula in Lev 26:12, "I will be your God and you will be my people"). For Christians, the New Covenant in Christ is the culminating point of the promises of salvation of the Old Covenant, and is to that extent never independent of it. The New Covenant is grounded in and based on the Old, because it is ultimately the God of Israel who concludes the Old Covenant with his people Israel and enables the New Covenant in Jesus Christ. Jesus lives during the period of the Old Covenant, but in his work of salvation in the New Covenant confirms and perfects the dimensions of the Old. The term covenant, therefore, means a relationship with God that takes effect in different ways for Jews and Christians. The New Covenant can never replace the Old but presupposes it and gives it a new dimension of meaning, by reinforcing the personal nature of God as revealed in the Old Covenant and establishing it as openness for all who respond faithfully from all the nations (cf. Zech 8:20-23; Psalm 87). 
28. Unity and difference between Judaism and Christianity come to the fore in the first instance with the testimonies of divine revelation. With the existence of the Old Testament as an integral part of the one Christian Bible, there is a deeply rooted sense of intrinsic kinship between Judaism and Christianity. The roots of Christianity lie in the Old Testament, and Christianity constantly draws nourishment from these roots. However, Christianity is grounded in the person of Jesus of Nazareth, who is recognised as the Messiah promised to the Jewish people, and as the only begotten Son of God who has communicated himself through the Holy Spirit following his death on the cross and his resurrection. With the existence of the New Testament, the question naturally arose quite soon of how the two testaments are related to one another, whether for example the New Testament writings have not superseded the older writings and nullified them. This position was represented by Marcion, who in the second century held that the New Testament had made the Old Testament book of promises obsolete, destined to fade away in the glow of the new, just as one no longer needs the light of the moon as soon as the sun has risen. This stark antithesis between the Hebrew and the Christian Bible never became an official doctrine of the Christian Church. By excluding Marcion from the Christian community in 144, the Church rejected his concept of a purely "Christian" Bible purged of all Old Testament elements, bore witness to its faith in the one and only God who is the author of both testaments, and thus held fast to the unity of both testaments, the "concordia testamentorum".

29. This is of course only one side of the relationship between the two testaments. The common patrimony of the Old Testament not only formed the fundamental basis of a spiritual kinship between Jews and Christians but also brought with it a basic tension in the relationship of the two faith communities. This is demonstrated by the fact that Christians read the Old Testament in the light of the New, in the conviction expressed by Augustine in the indelible formula: "In the Old Testament the New is concealed and in the New the Old is revealed" (Quaestiones in Heptateuchum 2, 73). Pope Gregory the Great also spoke in the same sense when he defined the Old Testament as "the prophecy of the New" and the latter as the "best exposition of the Old" (Homiliae in Ezechielem I, VI, 15; cf. "Dei verbum", 16).

30. This Christological exegesis can easily give rise to the impression that Christians consider the New Testament not only as the fulfillment of the Old but at the same time as a replacement for it. That this impression cannot be correct is evident already from the fact that Judaism too found itself compelled to adopt a new reading of Scripture after the catastrophe of the destruction of the Second Temple in the year 70. Since the Sadducees who were bound to the temple did not survive this catastrophe, the rabbis, following in the footsteps of the Pharisees, who had 
already developed their particular mode of reading and interpreting Scripture, now did so without the temple as the centre of Jewish religious devotion. ${ }^{37}$

31. As a consequence there were two responses to this situation, or more precisely, two new ways of reading Scripture, namely the Christological exegesis of the Christians and the rabbinical exegesis of that form of Judaism that developed historically. Since each mode involved a new interpretation of Scripture, the crucial new question must be precisely how these two modes are related to each other. But since the Christian Church and post-biblical rabbinical Judaism developed in parallel, but also in opposition and mutual ignorance, this question cannot be answered from the New Testament alone. After centuries of opposing positions it has been the duty of Jewish-Catholic dialogue to bring these two new ways of reading the Biblical writings into dialogue with one another in order to perceive the "rich complementarity" where it exists and "to help one another to mine the riches of God's word" ("Evangelii gaudium", 249). The document of the Pontifical Biblical Commission "The Jewish People and Their Sacred Scriptures in the Christian Bible" in 2001 therefore stated that Christians can and must admit "that the Jewish reading of the Bible is a possible one, in continuity with the Jewish Scriptures from the Second Temple period, a reading analogous to the Christian reading which developed in parallel fashion". It then draws the conclusion: "Both readings are bound up with the vision of their respective faiths, of which the readings are the result and expression. Consequently, both are irreducible" (No.22).

32. Since each of the two readings serves the purpose of rightly understanding God's will and word, it becomes evident how important is the awareness that the Christian faith is rooted in the faith of Abraham. That raises the further question of how the Old and the New Covenant stand in relation to one another. For the Christian faith it is axiomatic that there can only be one single covenant history of God with humanity. The covenant with Abraham, with circumcision as its sign (cf. Gen 17), and the covenant with Moses restricted to Israel regarding obedience to the law (cf. Ex 19:5; 24:7-8) and in particular the observance of the Sabbath (cf. Ex 31:16-17) had been extended in the covenant with Noah, with the rainbow as its sign (cf. "Verbum Domini", 117), to the whole of creation (cf. Gen 9:9 ff). Through the prophets God in turn promises a new and eternal covenant (cf. Is 55:3; 61:8; Jer 31:31-34; Ez 36:22-28). Each of these covenants incorporates the

\footnotetext{
37 "One thing is clear: the Bible - the Old Testament — had to be read anew. The Judaism of the Sadducees, which was entirely bound to the Temple, did not survive this catastrophe; Qumran - which despite its opposition to the Herodian Temple, lived in expectation of a renewed Temple - also disappeared from history. There are two possible responses to this situation, two ways of reading the Old Testament anew after the year 70: the reading in the light of Christ, based on the Prophets, and the rabbinical reading....After centuries of antagonism, we now see it as our task to bring these two ways of rereading the biblical texts - the Christian way and the Jewish way-into dialogue with one another, if we are to understand God's will and his word aright" (Benedict XVI, 2011, 34-35).
} 
previous covenant and interprets it in a new way. ${ }^{38}$ That is also true for the New Covenant which for Christians is the final eternal covenant and therefore the definitive interpretation of what was promised by the prophets of the Old Covenant, or as Paul expresses it, the "Yes" and "Amen" to "all that God has promised" (2 Cor 1:20). ${ }^{39}$ The Church as the renewed people of God has been elected by God without conditions. The Church is the definitive and unsurpassable locus of the salvific action of God. This however does not mean that Israel as the people of God has been repudiated or has lost its mission (cf. "Nostra aetate", No.4). The New Covenant for Christians is therefore neither the annulment nor the replacement, but the fulfilment of the promises of the Old Covenant.

33. For Jewish-Christian dialogue in the first instance God's covenant with Abraham proves to be constitutive, as he is not only the father of Israel but also the father of the faith of Christians. In this covenant community it should be evident for Christians that the covenant that God concluded with Israel has never been revoked but remains valid on the basis of God's unfailing faithfulness to his people, and consequently the New Covenant which Christians believe in can only be understood as the affirmation and fulfillment of the Old. Christians are therefore also convinced that through the New Covenant the Abrahamic covenant has obtained that universality for all peoples which was originally intended in the call of Abram (cf. Gen 12:1-3). This recourse to the Abrahamic covenant is so essentially constitutive of the Christian faith that the Church without Israel would be in

\footnotetext{
38 "The covenant has its concrete historical reference point in the people of Israel. This people exists in history and makes its way through history. Correspondingly, we repeatedly find new covenants sealed throughout the Old Testament: the covenant with Noah, guaranteeing the perpetual existence of the order of creation (cf. Gen 9:8-17), the covenant with Abraham containing the pledge of the Promised Land and numerous posterity (cf. Gen 17), the covenant with the people of Israel on Mt Sinai and their commitment to the 'Ten Words' (Decalogue) (cf. Ex 19 f; Deut 5). Further references include the renewal of this covenant after the entry into the Promised Land (cf. Josh 24) and the covenant with David and the promise that his throne will be established forever (cf. 2Sam 7:10-17). Also important, lastly, is the renewal of the covenant after the Babylonian exile and the promise of an everlasting covenant through the prophets (cf. Ezek 16:60, 37:26). Jer 31:31-34 is of particular significance because there the new covenant is expressly mentioned. It is of course a subject of debate whether this means a new covenant or a renewal of the Sinai covenant. These covenants do not stand in isolation, without any connection to one another. Each new covenant that is concluded refers back to the preceding one and restates it in current terms. Thus tradition and interpretation are in each instance interconnected....Each time the covenant is confirmed and renewed once more, God responds in his unconditional faithfulness to the constantly recurring unfaithfulness of his people. God perseveres in his commitment and renews it again and again in spite of the infidelity of his people. So again and again Israel is called to repentance and conversion (teschuva) (cf. Amos 4:6-12, Is 9:12ff and elsewhere)" (Kasper, 2004, §1).

39 - "God has spoken through Jesus Christ his definitive yes and amen to all the promises of salvation (2 Cor 1:20)" (Kasper, "Foreword," xv).

- "Thus Paul can say that in Christ Jesus all promises have become Yea and Amen (cf. 2Cor 1:20). In Christ the old covenant has not been abolished but has come into force in its definitive form, concentrating on its essence and accomplishing the universality implicit at its inception. So it has been upheld or elevated in a sense which is to be understood dialectically" (Kasper, 2004). See also Koch, 2011 and 2015.
} 
danger of losing its locus in the history of salvation. By the same token, Jews could with regard to the Abrahamic covenant arrive at the insight that Israel without the Church would be in danger of remaining too particularist and of failing to grasp the universality of its experience of God. In this fundamental sense Israel and the Church remain bound to each other according to the covenant and are interdependent. ${ }^{40}$

34. That there can only be one history of God's covenant with mankind, and that consequently Israel is God's chosen and beloved people of the covenant which has never been repealed or revoked (cf. Rom 9:4; 11:29), is the conviction behind the Apostle Paul's passionate struggle with the dual fact that while the Old Covenant from God continues to be in force, Israel has not adopted the New Covenant. In order to do justice to both facts Paul coined the expressive image of the root of Israel into which the wild branches of the Gentiles have been grafted (cf. Rom 11:16-21). One could say that Jesus Christ bears in himself the living root of the "green olive tree", and yet in a deeper meaning that the whole promise has its root in him (cf. Jn 8:58). This image represents for Paul the decisive key to thinking of the relationship between Israel and the Church in the light of faith. With this image Paul gives expression to the duality of the unity and divergence of Israel and the Church. On the one hand the image is to be taken seriously in the sense that the grafted wild branches have not their origin as branches in the plant onto which they are grafted and their new situation represents a new reality and a new dimension of God's work of salvation, so that the Christian Church cannot merely be understood as a branch or a fruit of Israel (cf. Mt 8:10-13). On the other hand, the image is also to be taken seriously in the sense that the Church draws nourishment and strength from the root of Israel, and that the grafted branches would wither or even die if they were cut off from the root of Israel (cf. "Ecclesia in Medio Oriente", 21). ${ }^{41}$

\section{The universality of salvation in Jesus Christ and God's unrevoked cove- nant with Israel}

35. Since God has never revoked his covenant with his people Israel, there cannot be different paths or approaches to God's salvation. The theory that there may be two different paths to salvation, the Jewish path without Christ and the path with the Christ, whom Christians believe is Jesus of Nazareth, would in fact endanger the foundations of Christian faith. Confessing the universal and therefore also exclusive mediation of salvation through Jesus Christ belongs to the core of Christian faith. So too does the confession of the one God, the God of Israel, who through his revelation in Jesus Christ has become totally manifest as the God of all peoples, insofar as in him the promise has been fulfilled ${ }^{42}$ that all peoples will

\footnotetext{
${ }^{40}$ See notes $12-13$

${ }^{41}$ Ibid.

${ }^{42}$ See note 32.
} 
pray to the God of Israel as the one God (cf. Is 56:1-8). The document "Notes on the correct way to present the Jews and Judaism in preaching and catechesis in the Roman Catholic Church" published by the Holy See's Commission for Religious Relations with the Jews in 1985 therefore maintained that the Church and Judaism cannot be represented as "two parallel ways to salvation", but that the Church must "witness to Christ as the Redeemer for all" (No. I, 7). The Christian faith confesses that God wants to lead all people to salvation, that Jesus Christ is the universal mediator of salvation, and that there is no "other name under heaven given to the human race by which we are to be saved" (Acts 4:12).

36. From the Christian confession that there can be only one path to salvation, however, it does not in any way follow that the Jews are excluded from God's salvation because they do not believe in Jesus Christ as the Messiah of Israel and the Son of God. Such a claim would find no support in the soteriological understanding of Saint Paul, who in the Letter to the Romans not only gives expression to his conviction that there can be no breach in the history of salvation, but that salvation comes from the Jews (cf. also Jn 4:22). ${ }^{43}$ God entrusted Israel with a unique mission, and $\mathrm{He}$ does not bring his mysterious plan of salvation for all peoples (cf. 1 Tim 2:4) to fulfillment without drawing into it his "first-born son" (Ex 4:22). From this it is self-evident that Paul in the Letter to the Romans definitively negates the question he himself has posed, whether God has repudiated his own people. Just as decisively he asserts: "For the gifts and the call of God are irrevocable" (Rom 11:29). That the Jews are participants in God's salvation is theologically unquestionable, but how that can be possible without confessing Christ explicitly, is and remains an unfathomable divine mystery. ${ }^{44}$ It is therefore

\footnotetext{
43 "According to the Christian faith understanding there can be only one path to salvation. However, on the other hand, it does not necessarily follow from this fundamental confession that the Jews are excluded from God's salvation because they do not believe in Jesus Christ as the Messiah of Israel and the Son of God. Such a claim would find no support in the soteriological understanding of St Paul, who in the Letter to the Romans definitively negates the question he himself has posed, whether God has repudiated his own people: 'For the gifts and the call of God are irrevocable' (Rom 11:29)" (Koch, Oct 29, 2012, §6. See also Koch, 2015 and 2011, 2d).

44 - "That the Jews are participants in God's salvation is theologically unquestionable, but how that can be possible without confessing Christ explicitly, is and remains an unfathomable divine mystery" (Koch, 2011. See also Koch, May, 16, 2012; Oct 29, 2012; 2015). "Such petitions for the coming of the Kingdom of God and for the realization of the mystery of salvation are not by nature a call to the Church to undertake missionary action to the Jews. Rather, they respect the whole depth of the Deus absconditus, of his election through grace, of the hardening and of his infinite mercy. So in this prayer the Church does not take it upon herself to orchestrate the realization of the unfathomable mystery. She cannot do so. Instead, she lays the when and the how entirely in God's hands. God alone can bring about the Kingdom of God in which the whole of Israel is saved and eschatological peace is bestowed on the world" (Kasper, 2008).

- "This does not mean that Jews in order to be saved have to become Christians; if they follow their own conscience and believe in God's promises as they understand them in their religious tradition they are in line with God's plan, which for us comes to its historical completion in Jesus Christ" (Kasper, 2002, §III).

- "[T]he Document Dominus Iesus does not state that everybody needs to become a Catholic in order to be saved by God. On the contrary, it declares that God's grace, which is the grace of Jesus
} 
no accident that Paul's soteriological reflections in Romans 9-11 on the irrevocable redemption of Israel against the background of the Christ-mystery culminate in a magnificent doxology: "Oh, the depth of the riches and wisdom and knowledge of God! How inscrutable are his judgments and how unsearchable his ways" (Rom 11:33). Bernard of Clairvaux (De cons. III/I, 3) says that for the Jews "a determined point in time has been fixed which cannot be anticipated". 45

37. Another focus for Catholics must continue to be the highly complex theological question of how Christian belief in the universal salvific significance of Jesus Christ can be combined in a coherent way with the equally clear statement of faith in the never-revoked covenant of God with Israel. ${ }^{46}$ It is the belief of the Church that Christ is the Savior for all. There cannot be two ways of salvation, therefore, since Christ is also the Redeemer of the Jews in addition to the Gentiles. $^{47}$ Here we confront the mystery of God's work, which is not a matter of

Christ according to our faith, is available to all. Therefore, the Church believes that Judaism, i.e. the faithful response of the Jewish people to God's irrevocable covenant, is salvific for them, because God is faithful to his promises" (Kasper, 2001).

- "According to Paul, 'all Israel will be saved' (Rom. 11:26ff.). This relates to the Pontifical Biblical Commission's observation that 'Jewish messianic expectation is not in vain' and therefore that at the end of time both Jews and Christians will recognize the 'One who is to come,' the eschatological messiah" (Kasper, "Foreword," xvii).

45 "[P] etitions for the coming of the Kingdom of God and for the realization of the mystery of salvation are not by nature a call to the Church to undertake missionary action to the Jews. Rather, they respect the whole depth of the Deus absconditus, of his election through grace, of the hardening and of his infinite mercy. So in this prayer the Church does not take it upon herself to orchestrate the realization of the unfathomable mystery. She cannot do so. Instead, she lays the when and the how entirely in God's hands. God alone can bring about the Kingdom of God in which the whole of Israel is saved and eschatological peace is bestowed on the world. In order to support this interpretation one can refer to a text of Bernard of Clairvaux, which says that we do not have to concern ourselves with the Jews, for God himself will take care of them. The correctness of this interpretation is demonstrated once more by the concluding doxology of the 11th chapter of the Letter to the Romans: ' $O$ the depth of the riches and wisdom and knowledge of God! How unsearchable are his judgments and how inscrutable his ways!' (11:33). This doxology demonstrates once more that the issue here is the glorification in adoration of God and of his unsearchable election through grace, and not a call to some kind of action, not even to mission" (Kasper, 2008, §IV).

46 - "A well thought-out determination of the relationship of Israel and the Church is fundamental to answering the question of Christian mission among the Jews. Every Christian reflection on this delicate subject must proceed from the universal salvific significance of Jesus Christ as well as from the universal mission of the church" (Kasper, "Foreword").

- "This involves especially such key issues as the Christian confession of Jesus as the Christ (i.e., the Messiah) and the Son of God, which is directly related to the Trinitarian understanding of biblical monotheism, the universal salvific significance of Jesus and other similar questions" (Kasper, 2010).

- "[A]t the suggestion of the Commission for Religious Relations with the Jews, an informally convened international group of Christian theologians began meeting in 2006; individual Jewish specialists and friends were invited to participate as critical observers. Their work studied the specific question of how to relate the universal saving significance of Jesus Christ to Israel's ongoing covenantal life with God" (Kasper, 2010).

47 - "If one takes the last statement seriously, then post-biblical Judaism and the church are not two covenant peoples: they are the one covenant people. They do not represent, therefore, two parallel ways of salvation" (Kasper, "Foreword"). 
missionary efforts to convert Jews ${ }^{48}$ but rather the expectation that the Lord will bring about the hour when we will all be united, "when all peoples will call on God with one voice and "serve him shoulder to shoulder" ("Nostra aetate", No.4).

38. The Declaration of the Second Vatican Council on Judaism, that is the fourth article of "Nostra aetate", is located within a decidedly theological framework regarding the universality of salvation in Jesus Christ and God's unrevoked covenant with Israel. That does not mean that all theological questions which arise in the relationship of Christianity and Judaism were resolved in the text. These questions were introduced in the Declaration, but require further theological reflection. Of course, there had been earlier magisterial texts which focused on Judaism, but "Nostra aetate" (No.4) provides the first theological overview of the relationship of the Catholic Church to the Jews.

39. Because it was such a theological breakthrough, the Conciliar text is not infrequently over-interpreted, and things are read into it which it does not in fact contain. An important example of over-interpretation would be the following: that the covenant that God made with his people Israel perdures and is never invalidated. Although this statement is true, it cannot be explicitly read into "Nostra aetate" (No. 4) ${ }^{49}$ This statement was instead first made with full clarity by Saint Pope John Paul II when he said during a meeting with Jewish representatives in Mainz on 17 November 1980 that the Old Covenant had never been revoked by God: "The first dimension of this dialogue, that is, the meeting between the people of God of the Old Covenant, never revoked by God ... and that of the New Covenant, is at the same time a dialogue within our Church, that is to say, between the first and the second part of her Bible" (No.3). The same conviction is stated also in the Catechism of the Church in 1993: "The Old Covenant has never been revoked" (121).

- "As distinct from the text of 1970 [of the Good Friday prayer for the Jews], the reformulated 1962 text speaks of Jesus as the Christ, the Savior of all mankind and therefore also of the Jews" (Kasper, 2008, §II).

48 "Such petitions for the coming of the Kingdom of God and for the realisation of the mystery of salvation are not by nature a call to the Church to undertake missionary action to the Jews. Rather, they respect the whole depth of the Deus absconditus, of his election through grace, of the hardening and of his infinite mercy" (Kasper, 2008, §IV).

${ }^{49}$ [Relevant Nostra aetate, $\$ 4$ sentences:] "The Church keeps ever in mind the words of the Apostle [Paul] about his kinsmen: 'theirs is [N.B. present tense] the sonship and the glory and the covenants and the law and the worship and the promises; theirs are the fathers and from them is the Christ according to the flesh' (Rom. 9:4-5) ..."; "God holds the Jews most dear for the sake of their Fathers; He does not repent of the gifts He makes or of the calls He issues - such is the witness of the Apostle"; and "Although the Church is the new people of God, the Jews should not be presented as rejected or accursed by God, as if this followed from the Holy Scriptures." 


\section{The Church's mandate to evangelize ${ }^{50}$ in relation to Judaism}

40. It is easy to understand that the so-called 'mission to the Jews' is a very delicate and sensitive matter for Jews because, in their eyes, it involves the very existence of the Jewish people. This question also proves to be awkward for Christians, because for them the universal salvific significance of Jesus Christ and consequently the universal mission of the Church are of fundamental importance. The Church is therefore obliged to view evangelization to Jews, who believe in the one God, in a different manner from that to people of other religions and world views. ${ }^{51}$ In concrete terms this means that the Catholic Church neither con-

50 - "Evangelizing mission, or more simply evangelization, refers to the mission of the Church in its totality....'to bring the Good News into all areas of humanity, and through its impact, to transform that humanity from within, making it new'...The Church accomplishes her evangelizing mission through a variety of activities....Yet...proclamation - kerygma, preaching or catechesis_occupies such an important place in evangelization that it has often become synonymous with it; and yet it is only one aspect of evangelization. In this document the term evangelizing mission is used for evangelization in its broad sense, while the more specific understanding is expressed by the term proclamation" (PCIDCEP, 1991, §8).

- "This touches the problem of mission towards Jews, a painful question with regard to forced conversion in the past. Dominus Iesus, as other official documents, raised this question again saying that dialogue is a part of evangelization. This stirred Jewish suspicion. But this is a language problem, since the term evangelization, in official Church documents, cannot be understood in the same way it is commonly interpreted in everyday's speech. In strict theological language, evangelization is a very complex and overall term, and reality. It implies presence and witness, prayer and liturgy, proclamation and catechesis, dialogue and social work. Now, presence and witness, prayer and liturgy, dialogue and social work, which are all part of evangelization, do not have the goal of increasing the number of Catholics. Thus evangelization, if understood in its proper and theological meaning, does not imply any attempt of proselytism whatsoever" (Kasper, 2001, §3).

- "In the light of the economy of salvation, the Church sees no conflict between proclaiming Christ and engaging in interreligious dialogue. Instead, she feels the need to link the two in the context of her mission ad gentes. These two elements must maintain both their intimate connection and their distinctiveness; therefore they should not be confused, manipulated or regarded as identical, as though they were interchangeable.... Dialogue does not originate from tactical concerns or self-interest, but is an activity with its own guiding principles, requirements and dignity. It is demanded by deep respect for everything that has been brought about in human beings by the Spirit who blows where he wills" (John Paul II, 1990, §§55, 56).

51 - "It is easy to understand that the term so-called 'mission to the Jews' is a very delicate and sensitive matter for the Jews because in their eyes it involves the very existence of Israel itself. On the other hand however, this question also proves to be awkward for us Christians too, because for us the universal salvific significance of Jesus Christ and consequently the universal mission of the church are of fundamental significance, especially since Paul on his missionary journeys always went first to the Jews in the synagogue, and only turned to the non-Jews after he had encountered resistance from the Jews. If one takes both sides of this delicate question seriously, the Christian church is obligated to perceive its evangelization task in respect of the Jews, who believe in the one God, in a different manner from that to the nations. This means, as Cardinal Kasper states, 'that the mission command is just as valid for Jews as for the nations, but it must be realized differently for the Jews in respect to the nations'“ (Koch, 2011).

- "This is for Jews a very delicate and sensitive question, because it implies for them the existence of Israel itself' (Kasper, 2010).

- "[M]ission understood as call to conversion from idolatry to the living and true God (1 Th 1:9) does not apply and cannot be applied to Jews. They confess the living true God, who gave and gives them support, hope, confidence and strength in many difficult situations of their history. There cannot be 
ducts nor supports any specific institutional mission work directed towards Jews. ${ }^{52}$ While there is a principled rejection of an institutional Jewish mission,

the same kind of behavior towards Jews as there exists towards Gentiles. This is not a merely abstract theological affirmation, but an affirmation that has concrete and tangible consequences such as the fact that there is no organized Catholic missionary activity towards Jews as is for all other nonChristian religions" (Kasper, 2002). See also Kasper, "Foreword."

52 - "That the Catholic church respects this fundamental difference [between Jews and other nonChristians] is evident above all in the fact that-in contrast to several fundamentalist and evangelical movements-it neither has nor supports any specific institutional mission work directed towards Jews. In his detailed examination of the question of the so-called mission to the Jews Cardinal Karl Lehmann rightly discerned that on closer investigation one finds 'as good as no institutional Jewish mission in Catholic mission history.' 'We have an abundant share in other forms of inappropriate attitudes towards the Jews and therefore have no right to elevate ourselves above others. But in respect to a specific and exclusive mission to the Jews there should be no false consternation or unjustified selfaccusation in this regard.' The rejection of an institutional mission to the Jews does not on the other hand exclude Christians from bearing witness to their faith in Jesus Christ also to Jews, but should do so in a humble and unassuming manner, particularly in view of the great tragedy of the Shoah" (Koch, 2011).

- "A well thought-out determination of the relationship of Israel and the Church is fundamental to answering the question of Christian mission among the Jews. Every Christian reflection on this delicate subject must proceed from the universal salvific significance of Jesus Christ as well as from the universal mission of the church. This was, of course, natural for Paul, too; this is why on his missionary journeys he went first (Rom 1:16) to the Jews in the synagogue, and only after he met opposition did he then turn to the Gentiles. It is nonetheless true that Jews are not pagans, they do not repent of false and dead idols to turn to the true and living God (1 Th 1:9). This means that command for mission is as valid for Jews as for pagans but it must be put into effect differently among Jews than pagans. This difference has not always been observed, and unfortunately there has been a history of forced conversions of Jews. In principle, though, the church takes this difference into account. In contrast to some fundamentalist movements, the Catholic Church sponsors no specific institutional missionary work aimed at Jews. This is more than a mere fact; it is an important ecclesial reality....According to Paul, 'all Israel will be saved' (Rom 11:26 ff). This relates to the Pontifical Biblical Commission's observation that 'Jewish messianic expectation is not in vain" and therefore that at the end of time both Jews and Christians will recognize the "One who is to come,' the eschatological messiah [PBC 2001, §21]. This does not mean that the church and the Christians should behave passively in the meantime and simply sit on their hands. The exclusion of a targeted institutional mission does not prohibit, but rather implies that the Christians and the church are generally required to give Jews witness to their faith in Jesus Christ now. Such Christian witness will be, especially after the Shoah, discreet and humble, must avoid any appearance of triumphalism, and show respect and esteem for the conviction of the Jewish partner" (Kasper, "Foreword," xvi-xvii). See also Kasper, 2010, §III and Kasper, 2008, §III.

- "The Roman Catholic reflections describe the growing respect for the Jewish tradition that has unfolded since the Second Vatican Council. A deepening Catholic appreciation of the eternal covenant between God and the Jewish people, together with a recognition of a divinely-given mission to Jews to witness to God's faithful love, lead to the conclusion that campaigns that target Jews for conversion to Christianity are no longer theologically acceptable in the Catholic Church" (BCEIA-NCS, 2002).

- "Hildegard Brem comments...as follows: 'In the light of Romans 11:25, the Church must not concern herself with the conversion of the Jews, since she must wait for the time fixed for this by God, until the full number of the Gentiles come in (Rom 11:25)... In the meantime, Israel retains its own mission. Israel is in the hands of God, who will save it 'as a whole' at the proper time, when the number of the Gentiles is complete. The fact that the historical duration of this period cannot be calculated is self-evident and should not surprise us. ... From this perspective, it can be understood that this 'time of the Gentiles' is not yet the full Messianic age in terms of the great salvation promises; but it remains the time of present history and suffering; yet in a new way it is also a time of hope: 'The night is far gone, the day is at hand' (Rom 13:12)" (Benedict XVI, 2011). 
Christians are nonetheless called to bear witness to their faith in Jesus Christ also to Jews, although they should do so in a humble and sensitive manner, acknowledging that Jews are bearers of God's Word, and particularly in view of the great tragedy of the Shoah. ${ }^{53}$

- "According to Roman Catholic teaching, both the Church and the Jewish people abide in covenant with God. We both therefore have missions before God to undertake in the world. The Church believes that the mission of the Jewish people is not restricted to their historical role as the people of whom Jesus was born 'according to the flesh' (Rom 9:5) and from whom the Church's apostles came. Nonetheless, the Church does perceive that the Jewish people's mission ad gentes (to the nations) continues. This is a mission that the Church also pursues in her own way according to her understanding of covenant. The command of the Resurrected Jesus in Matthew 28:19 to make disciples "of all nations" (Greek $=e t h n \bar{e}$, the cognate of the Hebrew $=$ goyim ; i.e., the nations other than Israel) means that the Church must bear witness in the world to the Good News of Christ so as to prepare the world for the fullness of the kingdom of God. However, this evangelizing task no longer includes the wish to absorb the Jewish faith into Christianity and so end the distinctive witness of Jews to God in human history. Thus, while the Catholic Church regards the saving act of Christ as central to the process of human salvation for all, it also acknowledges that Jews already dwell in a saving covenant with God. The Catholic Church must always evangelize and will always witness to its faith in the presence of God's kingdom in Jesus Christ to Jews and to all other people. In so doing, the Catholic Church respects fully the principles of religious freedom and freedom of conscience, so that sincere individual converts from any tradition or people, including the Jewish people, will be welcomed and accepted" (BCEIA-NCS, 2002).

53 - "The exclusion of an intentional and institutional mission to the Jews does not mean that Christians should sit about with their hands in their laps. One must distinguish between intentional and organized mission on the one hand and Christian witness on the other. Naturally, wherever appropriate, Christians must offer witness before their elder brothers and sisters in the faith of Abraham (John Paul II) to their faith and the richness and beauty of their belief in Jesus Christ. That is what Paul did. On his missionary journeys each time he went first to the synagogue and only when he found no faith there did he go to the Gentiles (Acts 13:5, 14ff., 42-52; 14:1-6ff.; principally Rom 1:16). Such witness is demanded of us today too. It should certainly be done tactfully and respectfully; but it would be dishonest if Christians in their encounters with Jewish friends remained silent about their faith or denied it. We expect the same of believing Jews towards us. In the dialogues with which I am familiar this behavior is altogether normal. An honest dialogue between Jews and Christians is only possible on the basis, first, of our shared belief in one God, Creator of heaven and earth, and in the promises given to Abraham and the fathers; and on the other hand in awareness and respect for the fundamental distinction, which consists in our belief in Jesus as the Christ and the Redeemer of all mankind" (Kasper, 2008, §5).

- "Such Christian witness will be, especially after the Shoah, discreet and humble" (Kasper, "Foreword"). See also Kasper, 2010, III.

- "As a means of removing any doubt as to our commitment to respect Jewish self-identity in our dialogues, and to promote deeper bonds of friendship and mutual understanding between the members of our two communities, we bishops affirm the following:...Catholics have a sacred responsibility to bear witness to Christ at every moment of their lives, but lived context shapes the form of that witness to the Lord we love. Jewish-Catholic dialogue, one of the blessed fruits of the Second Vatican Council, has never been and will never be used by the Catholic Church as a means of proselytism - nor is it intended as a disguised invitation to baptism. In sitting at the table, we expect to encounter Jews who are faithful to the Mosaic covenant, just as we insist that only Catholics committed to the teachings of the Church encounter them in our dialogues" (George et al., 2009).

- Dialogue can be understood in different ways. Firstly, at the purely human level, it means reciprocal communication, leading to a common goal or, at a deeper level, to interpersonal communion. Secondly, dialogue can be taken as an attitude of respect and friendship, which permeates or should permeate all those activities constituting the evangelizing mission of the Church. This can appropriately be called 'the spirit of dialogue.' Thirdly, in the context of religious plurality, dialogue means 'all positive and constructive interreligious relations with individuals and communities of other faiths 
41. The concept of mission must be presented correctly in dialogue between Jews and Christians. ${ }^{54}$ Christian mission has its origin in the sending of Jesus by the Father. He gives his disciples a share in this call in relation to God's people of Israel (cf. Mt 10:6) and then as the risen Lord with regard to all nations (cf. Mt 28:19). ${ }^{55}$ Thus the people of God attains a new dimension through Jesus, who calls his Church from both Jews and Gentiles (cf. Eph 2:11-22) ${ }^{56}$ on the basis of

which are directed at mutual understanding and enrichment' ['Dialogue and Mission,' §3], in obedience to truth and respect for freedom. It includes both witness and the exploration of respective relireligious convictions. It is in this third sense that the present document uses the term dialogue for one of the integral elements of the Church's evangelizing mission" (PCID-CEP, §9).

54 - "On the other hand, the term mission, in its proper sense, is referred to conversion from false gods and idols to the true and one God, who revealed himself in the salvation history with his elected people. Thus mission, in this strict sense, cannot be used with regard to Jews, who believe in the true and one God. Therefore - and this is characteristic - [there] does not exist any Catholic missionary organization for Jews. There is dialogue with Jews; no mission in this proper sense of the word towards them. But what is dialogue? Certainly - as we learned from Jewish philosophers such as Martin Buber-it is more than small talk and mere exchange of opinions. It is also different from academic dispute, however important academic dispute may be within dialogue. Dialogue implies personal commitments and witness of one's own conviction and faith. Dialogue communicates one's faith and, at the same time, requires profound respect for the conviction and faith of the partner. It respects the difference of the other and brings mutual enrichment" (Kasper, 2001, §3).

- "[The Second Vatican Council] understood that our two religious communities are connected and closely related at the very level of their respective religious identities. 'For the beginning of [the Church's] faith and election are already found among the patriarchs, Moses and the Prophets,' and 'therefore she cannot forget that she received the revelation of the Old Testament through the people with whom God in his inexpressible mercy deigned to establish the ancient covenant' [ibid.]. It is on the basis of all this that we recognize with utmost clarity that the path along which we should proceed with the Jewish religious community is one of fraternal dialogue and fruitful collaboration" (John Paul II, 1979).

- "Dialogue is born from a respectful attitude toward the other person, from a conviction that the other person has something good to say. It supposes that we can make room in our heart for their point of view, their opinion and their proposals. Dialogue entails a warm reception and not a preemptive condemnation. To dialogue, one must know how to lower the defenses, to open the doors of one's home and to offer warmth" (Bergoglio \& Skorka, 2013, xiv).

55 "For Christians this includes giving testimony of Jesus the Christ to all and in all places; for Christians this is the mandate of Jesus Christ himself (Matt 28, 19)" (Kasper, 2002).

56 - "For Paul the starting point is not the Sinai covenant but the covenant with Abraham. That is directed towards all peoples (cf. Gen 12:3; 17:4 etc); this universality must not be delimited by a law which is restricted to Israel.[16] On the cross Christ as our representative has fulfilled the law for us once and for all (cf. Rom 3:21-26; Gal 3:13; 4:4 f); he is thus the goal and the end of the law (cf. Rom 10:4; Gal 3:24).[17] Thus Christ has rescinded the exclusion of the Gentiles and given them access to the covenant; he has created peace and united and reconciled Jews and Gentiles in his person (cf. Eph 2:11-22). Thus Paul can say that in Christ Jesus all promises have become Yea and Amen (cf. 2Cor 1:20). In Christ the old covenant has not been abolished but has come into force in its definitive form, concentrating on its essence and accomplishing the universality implicit at its inception. So it has been upheld or elevated in a sense which is to be understood dialectically" (Kasper, 2004, §2).

- "In the New Testament Christ Jesus has taken the place of the Torah. All creation has been directed toward him and in him everything finds its fulfilment (cf. Jn 1:3-4.10; Col 1:16 f). In the church consisting of Jews and Gentiles (cf. Eph 2:11-22) the eschatological gathering of the peoples has already begun (cf. Is 2:2-5; Mic 4:1-5; Mt 8:11; Lk 13:29), but the promise made to Abraham has not yet been fulfilled completely. The remaining balance of the promise will only be fulfilled when in the end Israel too is saved (cf. Rom 11:2.32) and 'God may be all in all' (1Cor 15:28). Jews and Christians share a common root with one another and a common hope for one another. Regardless of 
faith in Christ and by means of baptism, through which there is incorporation into his Body which is the Church ("Lumen gentium", 14). ${ }^{57}$

42. Christian mission and witness, in personal life and in proclamation, belong together. The principle that Jesus gives his disciples when he sends them out is to suffer violence rather than to inflict violence. Christians must put their trust in God, who will carry out his universal plan of salvation in ways that only he knows, for they are witnesses to Christ, but they do not themselves have to im-

the Christological difference they are, in the current eschatological interim, two concurrent parts of God's one people on the basis of guilt and even greater grace, co-existing as rivals in the positive as well as in the conflict-ridden sense of the word. They have to follow the path of history beside one another" (Kasper, 2004, §6).

57 - "This Sacred Council wishes to turn its attention firstly to the Catholic faithful. Basing itself upon Sacred Scripture and Tradition, it teaches that the Church, now sojourning on earth as an exile, is necessary for salvation. Christ, present to us in His Body, which is the Church, is the one Mediator and the unique way of salvation. In explicit terms He Himself affirmed the necessity of faith and baptism and thereby affirmed also the necessity of the Church, for through baptism as through a door people enter the Church. Whosoever, therefore, knowing that the Catholic Church was made necessary by Christ, would refuse to enter or to remain in it, could not be saved....All the Church's children should remember that their exalted status is to be attributed not to their own merits but to the special grace of Christ. If they fail moreover to respond to that grace in thought, word and deed, not only shall they not be saved but they will be the more severely judged" (Lumen Gentium, §14).

- "[I]t must be firmly believed that "the Church, a pilgrim now on earth, is necessary for salvation: the one Christ is the mediator and the way of salvation; he is present to us in his body which is the Church. He himself explicitly asserted the necessity of faith and baptism (cf. Mk 16:16; Jn 3:5), and thereby affirmed at the same time the necessity of the Church which people enter through baptism as through a door' [citing Lumen gentium, 14; cf. Decree Ad gentes, 7; Decree Unitatis redintegratio, 3]. This doctrine must not be set against the universal salvific will of God (cf. 1 Tim 2:4); "it is necessary to keep these two truths together, namely, the real possibility of salvation in Christ for all mankind and the necessity of the Church for this salvation' [citing Redemptoris missio, §9; cf. Catechism of the Catholic Church, $\S \S 846-847$ ].... The Church is the 'universal sacrament of salvation' [citing Lumen Gentium, §48], since, united always in a mysterious way to the Savior Jesus Christ, her Head, and subordinated to him, she has, in God's plan, an indispensable relationship with the salvation of every human being [citing cf. St. Cyprian, De catholicae ecclesiae unitate, 6: CCSL 3, 253-254; St. Irenaeus, Adversus haereses, III, 24, 1: SC 211, 472-474]. For those who are not formally and visibly members of the Church, 'salvation in Christ is accessible by virtue of a grace which, while having a mysterious relationship to the Church, does not make them formally part of the Church, but enlightens them in a way which is accommodated to their spiritual and material situation. This grace comes from Christ; it is the result of his sacrifice and is communicated by the Holy Spirit' [citing John Paul II, Redemptoris Missio, §10]; it has a relationship with the Church, which 'according to the plan of the Father, has her origin in the mission of the Son and the Holy Spirit' [citing Ad Gentes, $\$ 2$ and incluuding this discursive comment: 'The famous formula extra Ecclesiam nullus omnino salvatur is to be interpreted in this sense (cf. Fourth Lateran Council, Cap. 1. De fide catholica: DS 802). Cf. also the Letter of the Holy Office to the Archbishop of Boston: DS 3866-3872]. With respect to the way in which the salvific grace of God - which is always given by means of Christ in the Spirit and has a mysterious relationship to the Church-comes to individual non-Christians, the Second Vatican Council limited itself to the statement that God bestows it 'in ways known to himself' [citing Ad Gentes, §7]. Theologians are seeking to understand this question more fully. Their work is to be encouraged, since it is certainly useful for understanding better God's salvific plan and the ways in which it is accomplished" (Dominus Iesus, VI, §§ 20-21).

- "Thus Christ has rescinded the exclusion of the Gentiles and given them access to the covenant; he has created peace and united and reconciled Jews and Gentiles in his person (cf. Eph 2:11-22)" (Kasper, 2004, §2). See also Kasper, 2002, §III. 
plement the salvation of humankind. Zeal for the "house of the Lord" and confident trust in the victorious deeds of God belong together. Christian mission means that all Christians, in community with the Church, confess and proclaim the historical realization of God's universal will for salvation in Christ Jesus (cf. "Ad gentes", 7). ${ }^{58}$ They experience his sacramental presence in the liturgy and make it tangible in their service to others, especially those in need.

43. It is and remains a qualitative definition of the Church of the New Covenant that it consists of Jews and Gentiles, even if the quantitative proportions of Jewish and Gentile Christians may initially give a different impression. ${ }^{59}$ Just as after the death and resurrection of Jesus Christ there were not two unrelated covenants, so too the people of the covenant of Israel are not disconnected from 'the people of God drawn from the Gentiles'. Rather, the enduring role of the covenant people of Israel in God's plan of salvation is to relate dynamically to the 'people of God of Jews and Gentiles, united in Christ', he whom the Church confesses as the universal mediator of creation and salvation. In the context of God's universal will of salvation, all people who have not yet received the gospel are aligned with the people of God of the New Covenant. "In the first place there is the people to whom the covenants and promises were given and from whom Christ was born according to the flesh (cf. Rom 9:4-5). On account of their fathers this people remains most dear to God, for he does not repent of the gifts he makes nor of the calls he issues (cf. Rom 11:28-29)" (“Lumen gentium”, 16).

\section{The goals of dialogue with Judaism}

44. The first goal of the dialogue is to add depth to the reciprocal knowledge of Jews and Christians. One can only learn to love what one has gradually come to know, and one can only know truly and profoundly what one loves. This profound knowledge is accompanied by a mutual enrichment whereby the dialogue partners become the recipients of gifts. ${ }^{60}$ The Conciliar declaration "Nostra aetate" (No.4) speaks of the rich spiritual patrimony that should be further discovered step by step through biblical and theological studies and through dialogue. To that extent, from the Christian perspective, an important goal is the mining of the spiritual treasures concealed in Judaism for Christians. In this regard one must mention above all the interpretation of the Sacred Scriptures. In the foreword by Cardinal Joseph Ratzinger to the 2001 document of the Pontifical Biblical Commission "The Jewish People and their Sacred Scriptures in the

\footnotetext{
58 "Therefore though God in ways known to Himself can lead those inculpably ignorant of the Gospel to find that faith without which it is impossible to please Him (Heb. 11:6), yet a necessity lies upon the Church (1 Cor. 9:16), and at the same time a sacred duty, to preach the Gospel” (Ad Gentes, §7).

59 "[In response to an interviewer's question, "May messianic Jews, who recognize Christ as a Messiah and fulfiller of their Judaism, be a bridge" between Christianity and Judaism?:] "They could be a bridge, and they are a reality which it is impossible to ignore. For very many Jews, however, the messianic communities represent a major challenge. This question therefore has to be considered very sensitively so as not to jeopardize the official dialogues with Judaism" (Koch, 2013).

${ }^{60}$ See notes 48-49.
} 
Christian Bible", the respect of Christians for the Jewish interpretation of the Old Testament is stressed. It highlights that "Christians can learn a great deal from a Jewish exegesis practiced for more than 2000 years; in return Christians may hope that Jews can profit from Christian exegetical research." ${ }^{.61}$ In the field of exegesis many Jewish and Christian scholars now work together and find their collaboration mutually fruitful precisely because they belong to different religious traditions.

45. This reciprocal acquiring of knowledge must not be limited to specialists alone. Therefore it is important that Catholic educational institutions, particularly in the training of priests, integrate into their curricula both "Nostra aetate" and the subsequent documents of the Holy See regarding the implementation of the Conciliar declaration. The Church is also grateful for the analogous efforts within the Jewish community. The fundamental changes in relations between Christians and Jews which were initiated by "Nostra aetate" (No. 4) must also be made known to the coming generations and be received and disseminated by them.

46. One important goal of Jewish-Christian dialogue certainly consists in joint engagement throughout the world for justice, peace, conservation of creation, and reconciliation. In the past, it may have been that the different religions - against the background of a narrowly understood claim to truth and a corresponding intolerance - contributed to the incitement of conflict and confrontation. But today religions should not be part of the problem, but part of the solution. Only when religions engage in a successful dialogue with one another, and in that way contribute towards world peace, can this be realized also on the social and political levels. Religious freedom guaranteed by civil authority is the prerequisite for such dialogue and peace. In this regard, the litmus-test is how religious minorities are treated, and which rights of theirs are guaranteed. In Jewish-Christian dialogue the situation of Christian communities in the state of Israel is of great relevance, since there - as nowhere else in the world - a Christian minority faces a Jewish majority. Peace in the Holy Land - lacking and constantly prayed for - plays a major role in dialogue between Jews and Christians.

47. Another important goal of Jewish-Catholic dialogue consists in jointly combating all manifestations of racial discrimination against Jews and all forms of anti-Semitism, which have certainly not yet been eradicated and re-emerge in dif-

\footnotetext{
${ }^{61}$ - "God continues to work among the people of the Old Covenant and to bring forth treasures of wisdom which flow from their encounter with his word. For this reason, the Church also is enriched when she receives the values of Judaism. While it is true that certain Christian beliefs are unacceptable to Judaism, and that the Church cannot refrain from proclaiming Jesus as Lord and Messiah, there exists as well a rich complementarity which allows us to read the texts of the Hebrew Scriptures together and to help one another to mine the riches of God's word" (Francis, 2014, §249).

- "After centuries of antagonism, we now see it as our task to bring these two ways of rereading the biblical texts - the Christian way and the Jewish way-into dialogue with one another, if we are to understand God's will and his word aright" (Benedict, 2011,35).
} 
ferent ways in various contexts. History teaches us where even the slightest perceptible forms of anti-Semitism can lead: the human tragedy of the Shoah in which two-thirds of European Jewry were annihilated. Both faith traditions are called to maintain together an unceasing vigilance and sensitivity in the social sphere as well. Because of the strong bond of friendship between Jews and Catholics, the Catholic Church feels particularly obliged to do all that is possible with our Jewish friends to repel anti-Semitic tendencies. Pope Francis has repeatedly stressed that a Christian can never be an anti-Semite, especially because of the Jewish roots of Christianity.

48. Justice and peace, however, should not simply be abstractions within dialogue, but should also be evidenced in tangible ways. The social-charitable sphere provides a rich field of activity, since both Jewish and Christian ethics include the imperative to support the poor, disadvantaged and sick. Thus, for example, the Holy See's Commission for Religious Relations with the Jews and the International Jewish Committee on Interreligious Consultations (IJCIC) worked together in 2004 in Argentina during the financial crisis in that country to organize joint soup kitchens for the poor and homeless, and to enable impoverished children to attend school by providing meals for them. Most Christian churches have large charitable organizations, which likewise exist within Judaism. These would be able to work together to alleviate human need. Judaism teaches that the commandment "to walk in His ways" (Deut 11:22) requires the imitation of the Divine Attributes (Imitatio Dei) through care for the vulnerable, the poor and the suffering (Babylonian Talmud, Sotah 14a). This principle accords with Jesus' instruction to support those in need (cf. e.g. Mt 25:35-46). Jews and Christians cannot simply accept poverty and human suffering; rather they must strive to overcome these problems.

49. When Jews and Christians make a joint contribution through concrete humanitarian aid for justice and peace in the world, they bear witness to the loving care of God. No longer in confrontational opposition but cooperating side by side, Jews and Christians should seek to strive for a better world. Saint Pope John Paul II called for such cooperation in his address to the Central Council of German Jewry and to the Conference of Rabbis in Mainz on 17 November 1980: "Jews and Christians, as children of Abraham, are called to be a blessing for the world..., by committing themselves together for peace and justice among all men and peoples, with the fullness and depth that God himself intended us to have, and with the readiness for sacrifices that this goal may demand".

\section{Cardinal KURT KOCH}

President

The Most Reverend BRIAN FARRELL

Vice-President

The Reverend NORBERT HOFMANN, SDB

Secretary 


\section{Abbreviations Used in the Annotated Text}

BCEIA-NCS, 2002

Delegates of the Bishops' Committee for Ecumenical and Interreligious Affairs and the National Council of Synagogues [United States], "Reflections on Covenant and Mission," Washington, D.C., August 12, 2002.

BCL, 1988

Bishops' Committee on the Liturgy, United States Conference of Catholic Bishops, God's Mercy Endures Forever: Guidelines on the Presentation of Jews and Judaism in Catholic Preaching, Washington, D.C., September 18, 1988.

Benedict XVI, 2005

Pope Benedict XVI, address delivered to the Roman Curia on the interpretation of the Second Vatican Council, Vatican City, December 22, 2005.

Benedict XVI, 2007

Pope Benedict XVI, Jesus of Nazareth: From the Baptism in the Jordan to the Transfiguration (New York: Doubleday, 2007).

Benedict XVI, Feb 12, 2009

Pope Benedict XVI, "Address to Delegates of the Conference of Presidents of Major American Jewish Organizations," Vatican City, February 12, 2009.

Benedict XVI, 2010

Pope Benedict XVI, “Address at the Great Synagogue of Rome,” January 17, 2010.

Benedict XVI, 2011

Pope Benedict XVI, Jesus of Nazareth: Holy Week: From the Entrance into Jerusalem to the Resurrection (New York: Doubleday, 2011).

Benedict XVI, 2012

Pope Benedict XVI, “Apostolic Exhortation Ecclesia in Medio Oriente," Vatican City, September 14, 2012.

Bergoglio \& Skorka, 2013

Jorge Mario Bergoglio and Abraham Skorka, On Heaven and Earth: Pope Francis on Faith, Family, and the Church in the Twenty-First Century (Alejandro Bermudez and Howard Goodman, trans.; New York: Image Books, 2013). First published in Spanish in 1995. 
Cassidy, 1998

Cardinal Edward Idris Cassidy, "Reflections Regarding the Vatican's Statement on the Shoah," address at the annual conference of the American Jewish Committee, Washington, D.C., May 28, 1998.

$\mathrm{CCC}$

Catechism of the Catholic Church (Washington, D.C.: United States Catholic Conference, 1994).

CRRJ, 1974

Commission of the Holy See for Religious Relations with the Jews, "Guidelines and Suggestions for Implementing the Conciliar Declaration Nostra Aetate, No. 4," Vatican City, December 1, 1974.

CRRJ, 1985

Commission of the Holy See for Religious Relations with the Jews, "Notes on the Correct Way to Present Jews and Judaism in Preaching and Catechesis in the Roman Catholic Church," Vatican City, June 24, 1985.

CRRJ, 1998

Commission of the Holy See for Religious Relations with the Jews, "We Remember: A Reflection on the Shoah," Vatican City, March 16, 1998.

Francis, 2014

Pope Francis, “Apostolic Exhortation Evangelii Gaudium," Vatican City, January 24, 2014, §§247-249.

Francis, 2015

Pope Francis, "General Audience Catechesis on 50th Anniversary of Nostra aetate," Vatican City, October 28, 2015.

George et al., 2009

Cardinal Francis George, Bishop Wilton D. Gregory, Cardinal William H. Keeler, Bishop William E. Lori, and Bishop William Murphy, "Statement of Principles for Catholic-Jewish Dialogue," Washington, D.C., October 2, 2009.

Hoffman, 2013

Norbert J. Hoffman, S.D.B., "Jews and Christians, Together as Witnesses to the One God," L'Osservatore Romano, January 17, 2013.

John Paul II, 1979

Saint Pope John Paul II, "Address to Representatives of Jewish Organizations," Vatican City, March 12, 1979. 
John Paul II, 1980

Saint Pope John Paul II, "Address to Representatives of the West German Jewish Community,” Mainz, West Germany, November 17, 1980.

John Paul II, 1986

Saint Pope John Paul II, “Address at the Great Synagogue of Rome," Rome, April 13, 1986.

John Paul II, 1990

Saint Pope John Paul II, Redemptoris Missio, December 7, 1990.

John Paul II, 1997

Saint Pope John Paul II, "Address to the Pontifical Biblical Commission," Vatican City, April 11, 1997.

John Paul II, 2000

Saint Pope John Paul II, "Homily at Mount Sinai," Mount Sinai, Egypt, February 26, 2000.

Kasper, 2001

Cardinal Walter Kasper, "Dominus Iesus," address delivered at the 17th meeting of the International Catholic-Jewish Liaison Committee, New York, May 1, 2001.

Kasper, 2002

Cardinal Walter Kasper, "The Commission for Religious Relations with the Jews: A Crucial Endeavour of the Catholic Church," address delivered at Boston College, Nov. 6, 2002.

Kasper, 2004

Cardinal Walter Kasper, "The Relationship of the Old and the New Covenant as One of the Central Issues in Jewish-Christian Dialogue," address delivered at the Centre for the Study of Jewish-Christian Relations, Cambridge, U.K., December 6, 2004.

Kasper, 2008

Cardinal Walter Kasper, "Striving for Mutual Respect in Modes of Prayer," L'Osservatore Romano (April 16, 2008): 8-9.

Kasper, 2010

Cardinal Walter Kasper, "Recent Developments in Jewish-Christian Relations," address delivered at Liverpool Hope University, May 24, 2010.

Kasper, "Foreword"

Cardinal Walter Kasper, "Foreword," in Philip A. Cunningham, Joseph Sievers, Mary C. Boys, Hans Hermann Henrix, and Jesper Svartvik, eds., Christ Jesus 
and the Jewish People Today. New Explorations of Theological Interrelationships (Grand Rapids, MI: Eerdmans, 2011), X-XVIII.

Koch, 2011

Cardinal Kurt Koch, "Theological Questions and Perspectives in Jewish-Catholic Dialogue," address delivered to the Council of Centers on Jewish-Christian Relations, Seton Hall University, South Orange, October 30, 2011.

Koch, May 16, 2012

Cardinal Kurt Koch, "Building on Nostra Aetate - 50 Years of Christian-Jewish Dialogue," address delivered at the Angelicum University in Rome under the auspices of the John Paul II Center for Interreligious Dialogue, May 16, 2012.

Koch, May 24, 2012

Cardinal Kurt Koch, "Christians Called to be Faithful to Abraham's Heritage," address was delivered at the Jerusalem Studies Institute in Jerusalem, Israel, May 24, 2012.

Koch, Oct 29, 2012

Cardinal Kurt Koch, "In the Service of Jewish-Catholic Understanding," address to consultors and delegates of individual Episcopal Conferences for CatholicJewish dialogue to the Commission of the Holy See for Religious Relations with the Jews, Rome, October 29, 2012.

Koch, 2013

Cardinal Kurt Koch, "Jewish-Catholic Dialogue and the dialogue between the Holy See and Judaism," interview by Oliver Maksan of the Catholic charity Aid to the Church in Need before a meeting of the Joint Commission for the JewishCatholic Dialogue in Jerusalem, May 9, 2013.

Koch, 2015

Cardinal Kurt Koch, "The International Dialogue between the Catholic Church and the Jews since Nostra Aetate," address delivered at the Catholic University of America, Washington, D.C., May 20, 2015. See Origins 45/6 (June 11, 2015): 8289.

NCCB, 1975

National Conference of Catholic Bishops [United States], "Statement on Catholic-Jewish Relations," Washington, D.C., November 20, 1975.

PBC, 2001

Pontifical Biblical Commission, "The Jewish People and Their Sacred Scriptures in the Christian Bible," Vatican City, May 24, 2001. 
PCID-CEP, 1991

Pontifical Council for Interreligious Dialogue in collaboration with the Congregation for the Evangelization of Peoples, "Dialogue and Proclamation: Reflection and Orientations on Interreligious Dialogue and the Proclamation of the Gospel of Jesus Christ," May 19, 1991.

Ratzinger, 2000

Cardinal Joseph Ratzinger, "The Heritage of Abraham: The Gift of Christmas," L' Osservatore Romano, December 29, 2000. 